\title{
District heating and cogeneration in the EU-28: Current situation, potential and proposed energy strategy for its generalisation
}

\author{
Enrique Rosales-Asensio ${ }^{1}$ \{enrique.rosales.uned@gmail.com \\ David Borge-Diez ${ }^{1,2}$ \{david.borge@unileon.es\} \\ ${ }^{1}$ Department of Electric, Electronic and Control Engineering, UNED \\ Juan del Rosal, 12 - Ciudad Universitaria. 28040 Madrid - SPAIN \\ Phone +34-913-987-788 Fax +34-913-986-028 \\ ${ }^{2}$ Dpto. de Ing. Eléctrica y de Sistemas y Automática, Universidad de León \\ Campus de Vegazana s/n. Escuela de Ingenierías. 24071 León \\ Tf: (+34) 98729 19 93; Fax: (+34) 987291790
}

Received: 2016-05-12; Accepted: 2016-08-11

\begin{abstract}
Yearly, EU-28 conventional thermal generating plants reject a greater amount of energy than what ultimately is utilised by residential and commercial loads for heating and hot water. If this waste heat were to be used through district heating networks, given a previous energy valorisation, there would be a noticeable decrease in imported fossil fuels for heating. As a consequence, benefits in the form of an energy efficiency increase, an energy security improvement, and a minimisation of emitted greenhouse gases would occur. Given that it is not expected for heat demand to decrease significantly in the medium term, district heating networks show the greatest potential for the development of cogeneration. However, to make this happen, some barriers that are far from being technological but are mostly institutional and financial need to be removed. The purpose of this review is to provide information on the potential of using waste heat from conventional thermal power plants (subsequently converted into cogeneration plants) in district heating networks located in the EU-28. For this, a preliminary assessment is conducted in order to show an estimate of the cost of adopting an energy strategy in which district heating networks are a major player of the energy mix. From this assessment, it is possible to see that even though the energy strategy proposed in this paper, which is based on a dramatic increase in the joint use of district
\end{abstract}


heating networks and cogeneration, is capital-intensive and would require an annual investment of roughly 300 billion euros, its adoption would result in a reduction of yearly fuel expenses in the order of 100 billion euros and a shortening of about $15 \%$ of the total final energy consumption, which makes it of paramount interest as an enabler of the legal basis of the "Secure, Clean and Efficient Energy" future enacted by the EU-28 Horizon 2020 .

Keywords: district heating networks, cogeneration, energy potential, EU-28

\section{Nomenclature and units}

$\begin{array}{ll}\text { AHDD } & \text { annual heat demand per dwelling } \\ \text { DCNs } & \text { district cooling networks } \\ \text { DHNs } & \text { district heating networks } \\ \text { HHW } & \text { heating and hot water } \\ \text { HPR } & \text { heat to power ratio } \\ \text { LAs } & \text { local authorities } \\ \text { LF } & \text { load factor }\end{array}$




\section{Introduction}

From the simplified energy balances performed annually by EUROSTAT (2013 is the last year for which data is available), conventional thermal power plants located in the EU-28 waste more energy in the form of residual heat than what finally residential and commercial buildings use for heating [1,2]. As is clear from (Fig. 1), if this residual heat could be used previous energy valorisation from cogeneration in district heating networks, a noticeable decrease in the amount of imported fossil fuels and greenhouse gases emitted into the atmosphere would occur (in the Theoretical Background section, additional information on the relation between electricity and heat in a cogeneration plant is included), which would result in economic, environmental, and energy security benefits.

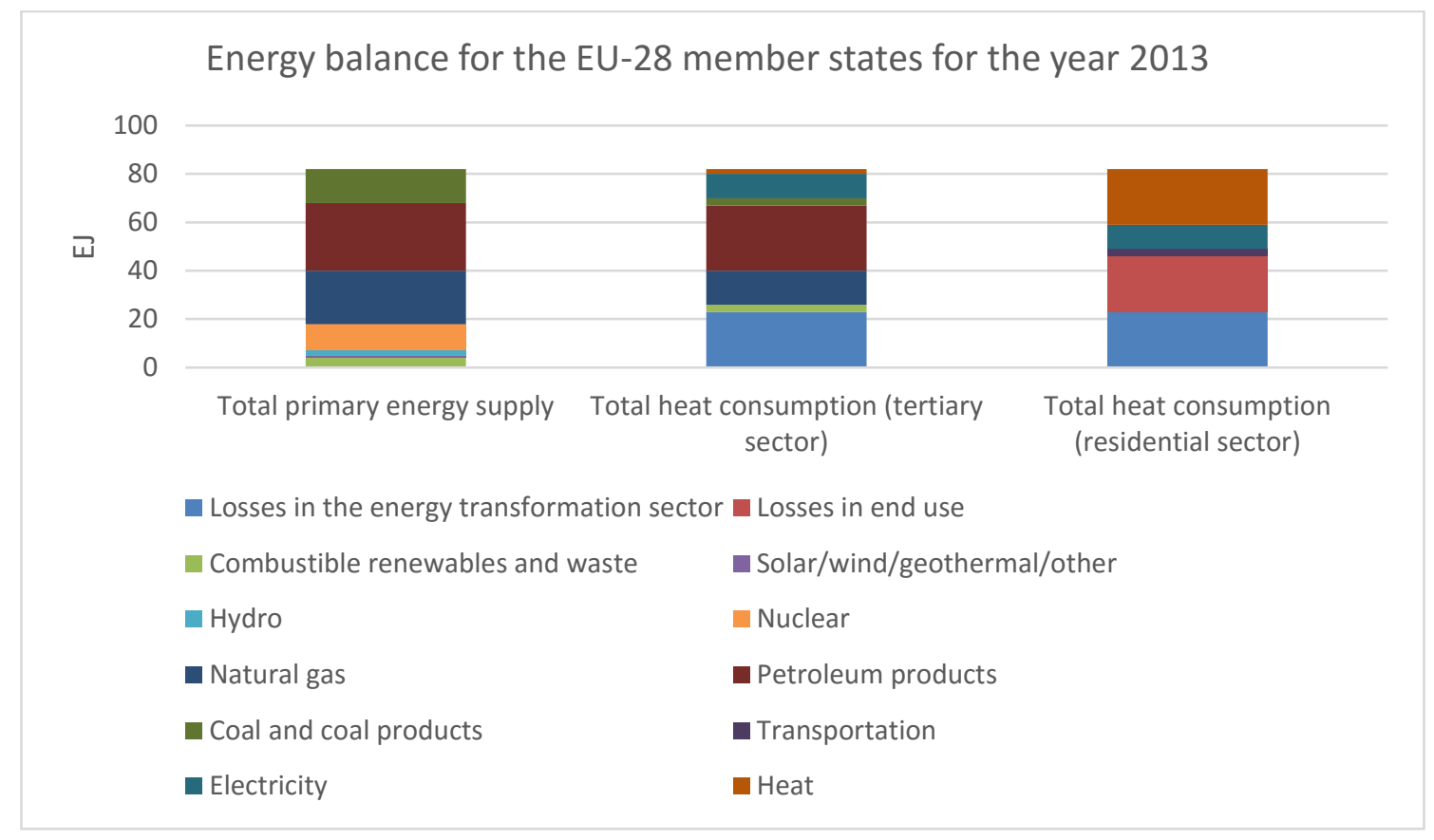

Figure 1. Energy balance for the EU member states for the year 2013 [2]

From (Fig. 1), it is impossible to determine how much heat can be used. Many power plants have to be necessarily located far from the thermal loads of cities (e.g., coal power plants are usually located close to a port to stock). However, in a future scenario, it could be more beneficial, from an economic perspective, to place those plants in the vicinity of the cities. As they are environmentally friendly they can be located closer to them. The old plants should be dismantled when their useful life ends. This supposes an additional expense of transporting coal or lignite in order to be able to use waste heat from power plants [3]. 
In (Fig. 2), it can be seen as another way of representing the energy balance (which again shows the importance of waste heat from power plants) [4].

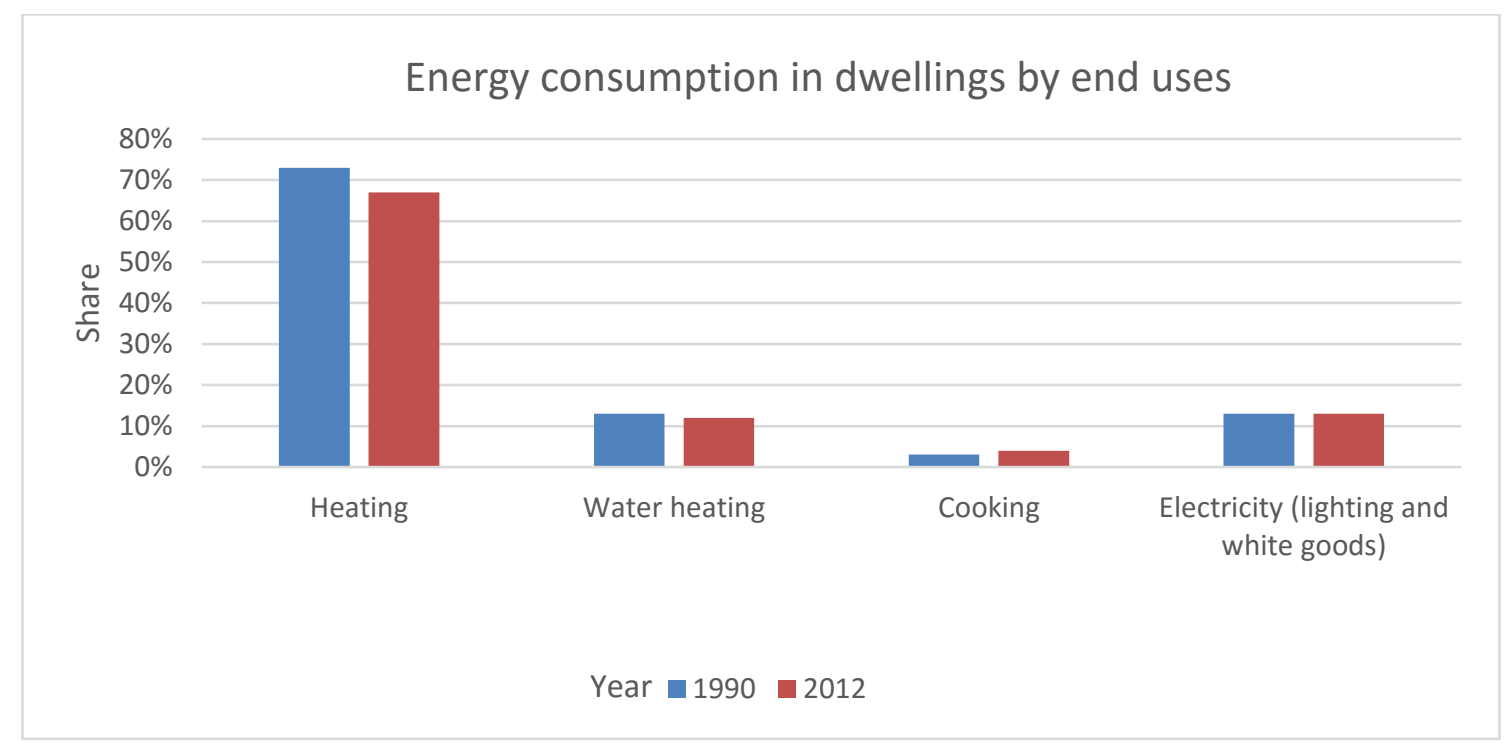

Figure 2. Power consumption for households located in the European Union depending on the energy end-use. Source: Adapted from [5]

As seen in (Fig. 3), about $80 \%$ of the energy used in homes has as ultimate goal to provide heating and hot water; this means that, according to (Fig. 2), there would be potentially about $15000 \mathrm{PJ} /$ year $(4100 \mathrm{TWh})$ to be satisfied through the waste heat from power plants (note that this amount is less than the residual heat emitted by power plants located in the EU-28, 19608 PJ/year; Fig. 2). Finally, (Fig. 4) shows the energy share for each district heating resource - it is possible to see that, for the EU, most of the heat comes from waste heat from power plants. 


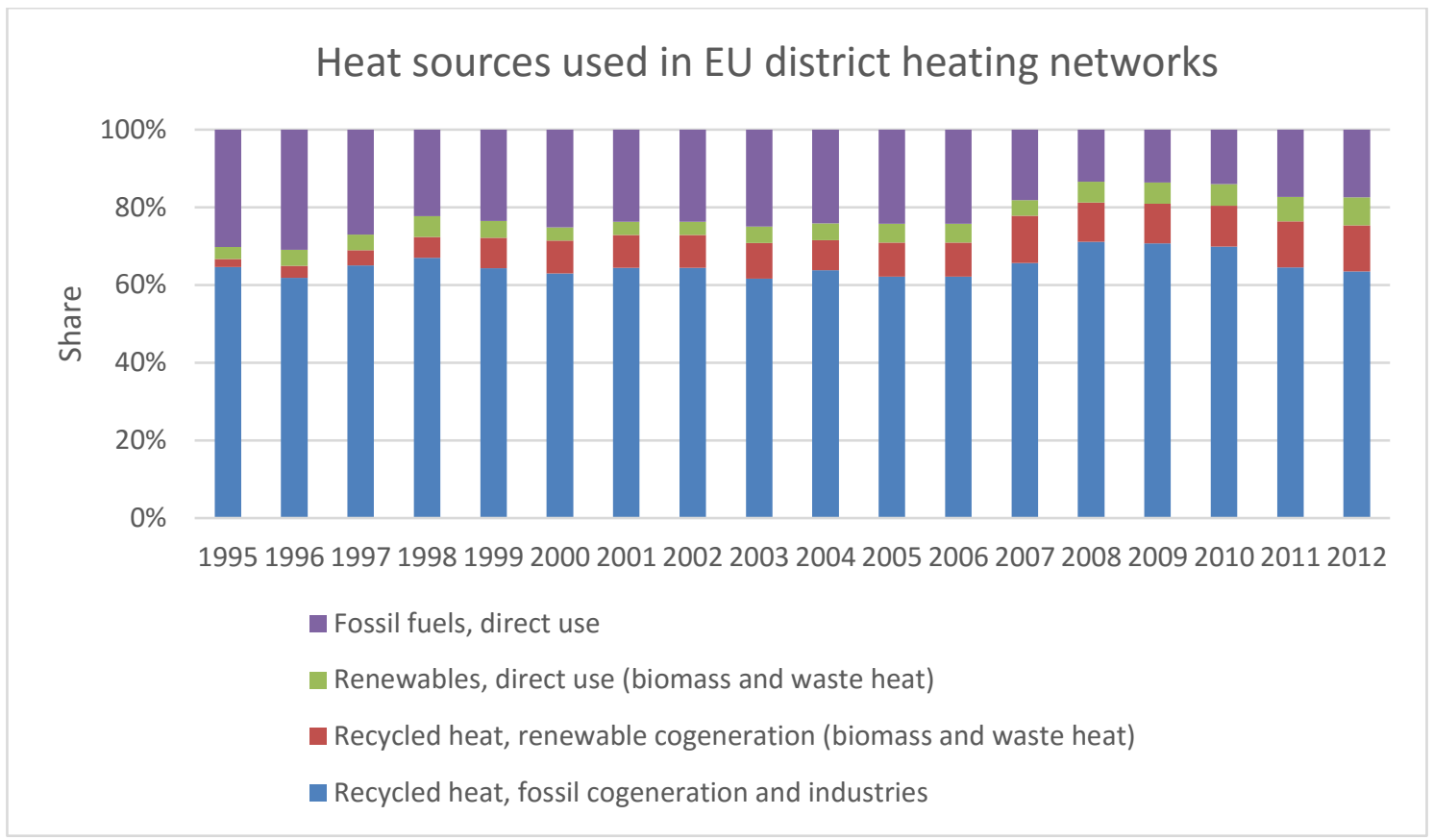

(a)

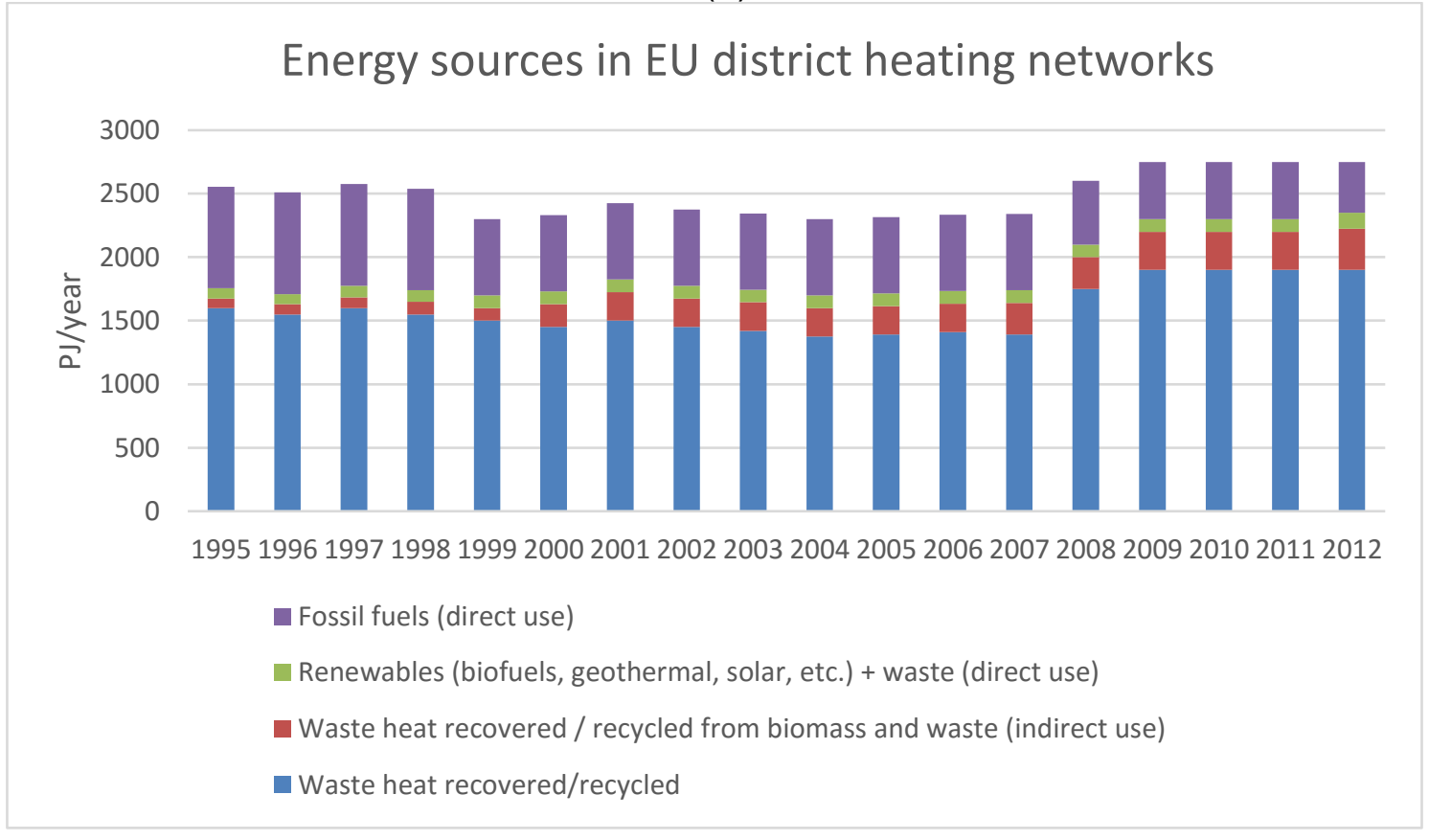

(b)

Figure 3. Energy share (a) and generation for each district heating source (b) in the EU28 [10] 
Despite these data, it should be noted that, due to the lack of energy matching throughout the year, as well as to the problem of the reject heat temperature (cogeneration can conduct an energy valorisation of this low-temperature heat in an economical way), not all of these thermal loads can be satisfied by the waste heat from thermal power plants. This makes necessary to estimate their real potential including assumptions as close as possible to the reality and to conduct an economic and environmental assessment (reduction of greenhouse gas emissions) that includes a generalised spread of district heating networks using as an energy source waste heat from conventional thermal power plants in the EU-28, which will be conducted in this review.

The objective of this paper is to propose an energy strategy which enables, through the generalisation of the joint use of district heating networks and cogeneration in the EU-28, the fulfillment of the legal basis of the H2020 "Secure, Clean, and Efficient Energy" goals in a feasible, reliable, economically advantageous, and sustainable way. The method proposed here uses a systematic and easy approach (neither strong mathematical skills nor non-widely used software is required) and manages to propose an energy strategy for such a big region as EU-28 based mostly on available public data (with the exception of the plant data obtained through the GESTIS database by using the ArcGIS software). This is of great importance as other methods are network-oriented (district heating network); lack from massive surface applicability [6], being inadequate for such a big area as Europe; are limited to industrial sites [7]; or present assessments which need a district heating network taxonomy [8], information not available in the vast majority of the cases. As a consequence, they are not useful for the purposes of this paper. To our knowledge, there is not a single scientific paper which specifically addresses the potential of the joint use of thermal power plant reject heat into district heating networks across the European Union. Thus, we offer new insights into this matter.

In the first section, the first approach to the energy balance of the EU-28 member states is described, and the potential of using the waste heat from conventional thermal power plants is discussed. Meanwhile, the second section will present the methodology used to develop the review conducted here. In the third section, studies evaluating the potential of using jointly district heating networks and cogeneration for different regions will be presented. In this section, information regarding prices of district heating networks, transport, distribution, and thermal storage, as well as a presentation of the case of Copenhagen as an example of a city that has succeeded in combining electricity, district heating networks, natural gas, and waste management properly is presented. In the fourth section, different scenarios on the evolution of district heating networks and the estimated economically feasible conventional thermal power plant conversion potential will be presented. The fifth section is reserved for the discussion, and the sixth section presents the conclusion, in which the implications (restrictions and benefits) that 
the generalisation of the joint use of cogeneration and district heating networks in the EU28 will be shown.

\section{Material and Methods}

To give documentary strength to this review, it was necessary in the first instance to consult more than 100 scientific publications and/or gray literature in the field of cogeneration and district heating networks. While not absolute, it is a representative sample of the state of the art of the subject under study.

Subsequently, and to determine the degree of matching between the above publications and the perception of experts from various members of the EU-28, a total of nine experts from seven countries of the European Union (see section "Acknowledgements") were consulted through questionnaires, email correspondence and/or telephone conversations.

Once the scientific/gray literature and the experts were consulted, the third step taken was to use various databases to estimate the potential for the joint utilisation of district heating networks and cogeneration. Among these databases, the most notable were EUROSTAT, GESTIS database based on Platts, and The European Pollutant Release and Transfer Register (European Environment Agency). The latter was essential for selecting those conventional ones potentially convertible in an economical way.

The fourth step taken was to introduce some restrictions on the type of plant and the distance from it to the thermal load (nearest town). To estimate the cost related to the heat demand, member states of the EU-28 were firstly divided into zones, with the countries of central and southern Europe assigned a cost on energy demand different from the one used only for the countries of southern Europe. This discrimination is based on the fact that, obviously, the costs of providing heat to the thermal loads decrease as demand increases.

Finally, and in order to know the cost of providing heat through district heating networks for different typical climatic zones of the EU-28, [11] was consulted, which constitutes a supporting feature to the review presented here. To the heat demand for each consumption located in Northern and Central Europe, a value of $2000 \mathrm{GWh} /$ year was assigned, having been established the distance from the heat load at $75 \mathrm{~km}$. Meanwhile, for those loads located in the Southern European countries, a type value of $750 \mathrm{GWh} /$ year of heat and 400 $\mathrm{GWh} /$ year for cooling was established, being the distance in this case also $75 \mathrm{~km}$. Note that these conditions are much more restrictive than those described in [11]; we have proceeded in this way because such cases, although based on real plants, have better characteristics for the conversion to cogeneration plants than those that would be considered as "typical". 
Due to the fact that DHNs and DCNs lack a symmetrical end-use purpose (DHNs are usually aimed at areas where there are residential buildings within a city, while DCNs tend to be focused only on the central areas of the cities) and its proximity-to-load requirement, it is not possible to distribute cold appropriately from an economic perspective. District cooling is based on a difference of temperatures much smaller than district heating; see in Theoretical Background section for additional information on the distribution of heat and cold in modern heating/cooling systems) [12]. It would be impractical to transmit the cold at a distance of $75 \mathrm{~km}$, so for the countries of Southern Europe, it has been supposed the use of absorption heat units that use the heat from district heating networks for cooling, not being, therefore, necessary to use pipes for transporting cold at a large scale.

Some restrictions have been imposed, e.g. only those thermal power plants with a rated power of over $300 \mathrm{MW}$ located within $75 \mathrm{~km}$ of urban centers of more than 100000 inhabitants are considered as valid for conversion, and some data such as the following was found out:

- total installed capacity of thermal power plants using fossil fuels

- total installed capacity of cogeneration

- CHP generation percentage

- CHP maximum installable capacity from thermal plants

From this data, a feasible CHP capacity that would comply with the aforementioned restrictions is obtained and presented in the Results section. From these feasible convertible thermal power plants and from data obtained from the literature, usable heat, the investment needed, and fuel savings are obtained and shown in the Results section.

A summary of every stage of study and its relationship with the Results section would be as follows:

1) Scientific publicatons and/or gray literature review.

2) Experts in the field of cogeneration and district heating networks consultation.

3) Databases (EUROSTAT, GESTIS, and The European Pollutant Release and Transfer Register) consultation.

- The obtainment of conventional thermal combustion capacity, CHP electrical capacity, share of CHP electricity production, electricity generation from generation plants, heat generation from CHP plants, final total energy consumption, total district heating network sales, and percentage of citizens served by district heating, is immediate from EUROSTAT databases.

- The methodology to assemble the data obtained from GESTIS and EPRTR was as follows:

a. Plant data: GESTIS database based on Platts 
i. This data was accessed through the GESTIS database using the ArcGIS software.

b. Plant coordinates: EPER/ E-PRTR database

i. It can be accessed through the European Pollutant Release and Transfer Register website. Then following steps were undertaken "Search the register"> "Facility level"> "Country"> "EU27"> "Region"> "All regions"> "Year"> "2013"> "Industrial activity"> "Energy sectors" > "Thermal power stations and other combustion industries" > "No sub-activities"

c. City coordinates: Google Earth

i. No description needed

4) Calculation of maximum conversion of CHP by using total conventional thermal combustion capacity and CHP electrical capacity; heat to power ratio by using heat generation from CHP plants and electricity generation from CHP plants; and maximum annual additional heat output by using the maximum conversion of CHP calculated, the heat to power ratio, and supposing a load factor of 0.6.

5) Restrictions on the type of plant (only conventional thermal plants with a rated power of over $300 \mathrm{MW}$ are to be considered), distance (thermal plants shall be located at a distance below to $75 \mathrm{~km}$ of urban centers), population of urban centers (higher to 100000 inhabitants) and heat demand in Northern and Central Europe (2000 GWh/year) and heat and cooling demand in Southern Europe (respectively $750 \mathrm{GWh} /$ year and $400 \mathrm{GWh} /$ year) are applied.

6) Calculation of DHNs feasible potential by using the maximum annual additional heat and the fact that, after the restrictions imposed in 5), about 50\% of the installed capacity of all conventional thermal power plants comply with those restrictions; calculation of conversion and district heating costs by classifying countries into Regions (Norhtern and Central Europe and Southern Europe) and taking into account heating (and cooling) costs in those regions.

7) Once DHNs' feasible potential is achieved and yearly savings in fuel are known, the cost of natural gas for domestic consumption is determined, and the usual fuel consumption per unit of heat supplied for boilers and cogeneration plants (for both cases separately) are assumed. Through the cost difference between the two technologies, fuel savings are obtained.

8) Finally, the results from previous steps (1 to 7) are analysed, and an energy strategy for the generalisation of district heating networks and cogeneration is proposed, achieving, consequently, the objectives of the research. 


\section{Theoretical Background}

To know the true potential of any technology, in this case, the joint use of cogeneration and district heating networks, it is necessary to perform an assessment of its economic feasibility. In the existing literature, it is possible to find a relatively high volume of gray literature and scientific publications that carry out feasibility studies relating to the implementation of district heating networks.

One of the first was conducted in 1979 by the Ministry of Energy of the United Kingdom [13], where it was indicated that the joint use of cogeneration and district heating networks was competitive already at that time from an economic perspective in comparison to the fuels used to satisfy the heating demand (the largest infrastructural costs were offset by lower operating costs). This study recommended the development of a program that would implement district heating networks associated with cogeneration plants. Although this publication saw the light more than three decades ago, the results remain equally valid because, firstly, the technical installation of the district heating networks have improved and the costs have decreased [14] and, secondly, comparatively fuel-related costs have increased more than the cost of the necessary infrastructure [15].

A computerised methodology to estimate the potential of the joint use of cogeneration and district heating for various discount rates was used [16]. As shown in (Table 1), it is only in the UK with a peak demand of $60 \mathrm{GW}$ [17] that there is a potential of $33 \mathrm{GW}$ for this technology for a discount rate of 3.5\%. Due to similar weather conditions, this study is representative for much of northern and central Europe. As is clear from (Table 1) and (Fig. 4 ), the choice of the discount rate is crucial to the feasibility of the project.

Table 1. Potential joint use of cogeneration and district heating networks in the UK for various discount rates [16]

\begin{tabular}{lllll}
\hline CH/CHP potential & Units & \multicolumn{3}{c}{ Discount rate } \\
\cline { 3 - 5 } & & $\mathbf{3 . 5 \%}$ & $\mathbf{6 \%}$ & $\mathbf{9 \%}$ \\
\hline Total net CH/CHP potential for UK & MWe & 33125 & 21517 & 75 \\
\hline Total electricity produced & - & 6897 & 4204 & 46 \\
\hline Total heat sold & GWh & 189472 & 123119 & 518 \\
\hline Primary energy saving & GWh & 230358 & 149686 & 630
\end{tabular}

In $[18,19]$, the possibility of using cogeneration and district heating networks is studied again, reaching similar conclusions. As is clear from these publications, the joint use of these technologies provokes one of the greatest savings, in terms of $\mathrm{CO}_{2}$ emissions, at one of the lowest costs per not emitted tonne [18,19] (Fig. 4 and Fig. 5). 


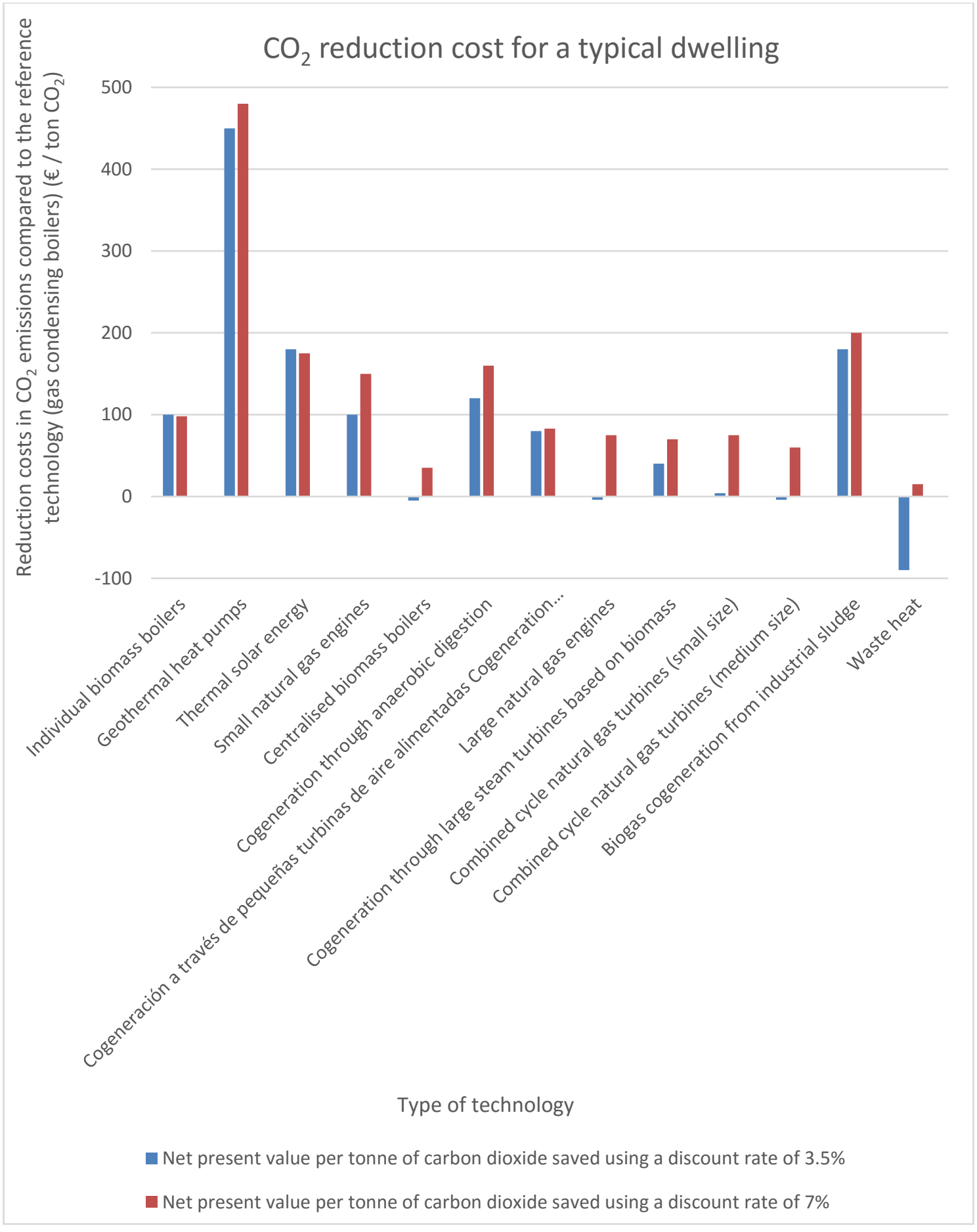

Figure 4. The cost of $\mathrm{CO}_{2}$ reduction for the typical UK dwelling [18] 


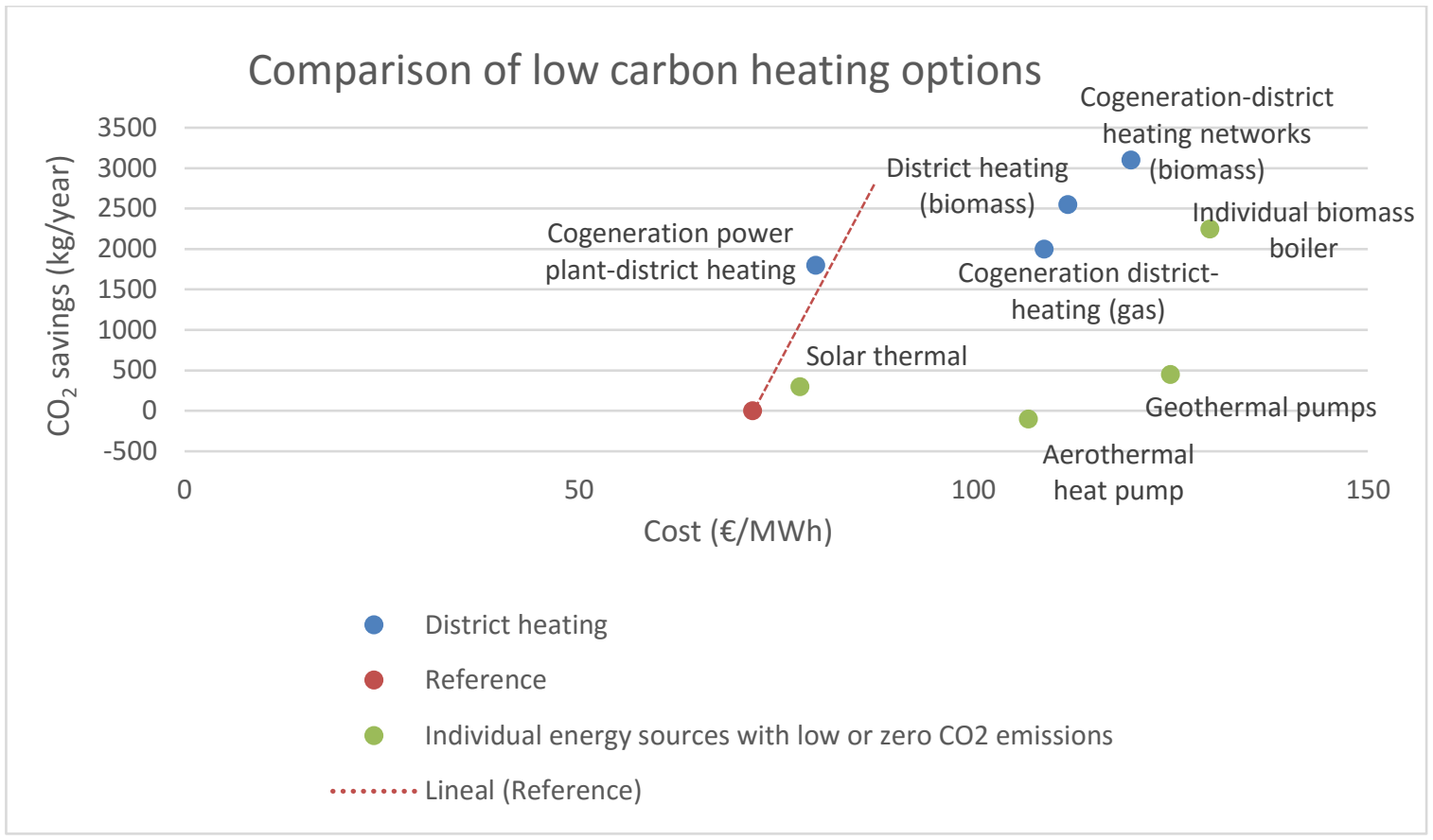

Figure 5. Comparison of different energy solutions with low emissions of carbon dioxide [19]

At a European level, [20] confirms the possibility of stopping to emit $400 \mathrm{MtCO}_{2}$ per year, which would mean a reduction of $9 \%$ compared to current emissions, if the penetration of district heating and cooling were to be doubled.

To give documentary strength to this review, information regarding prices of district heating networks, transport, distribution, and thermal storage, as well as a presentation of the case of Copenhagen as an example of a city that has succeeded in combining electricity, district heating networks, natural gas, and waste management properly is presented in this Theoretical Background section as follows. 


\subsection{Sankey diagram with the EU energy balance for 2012}

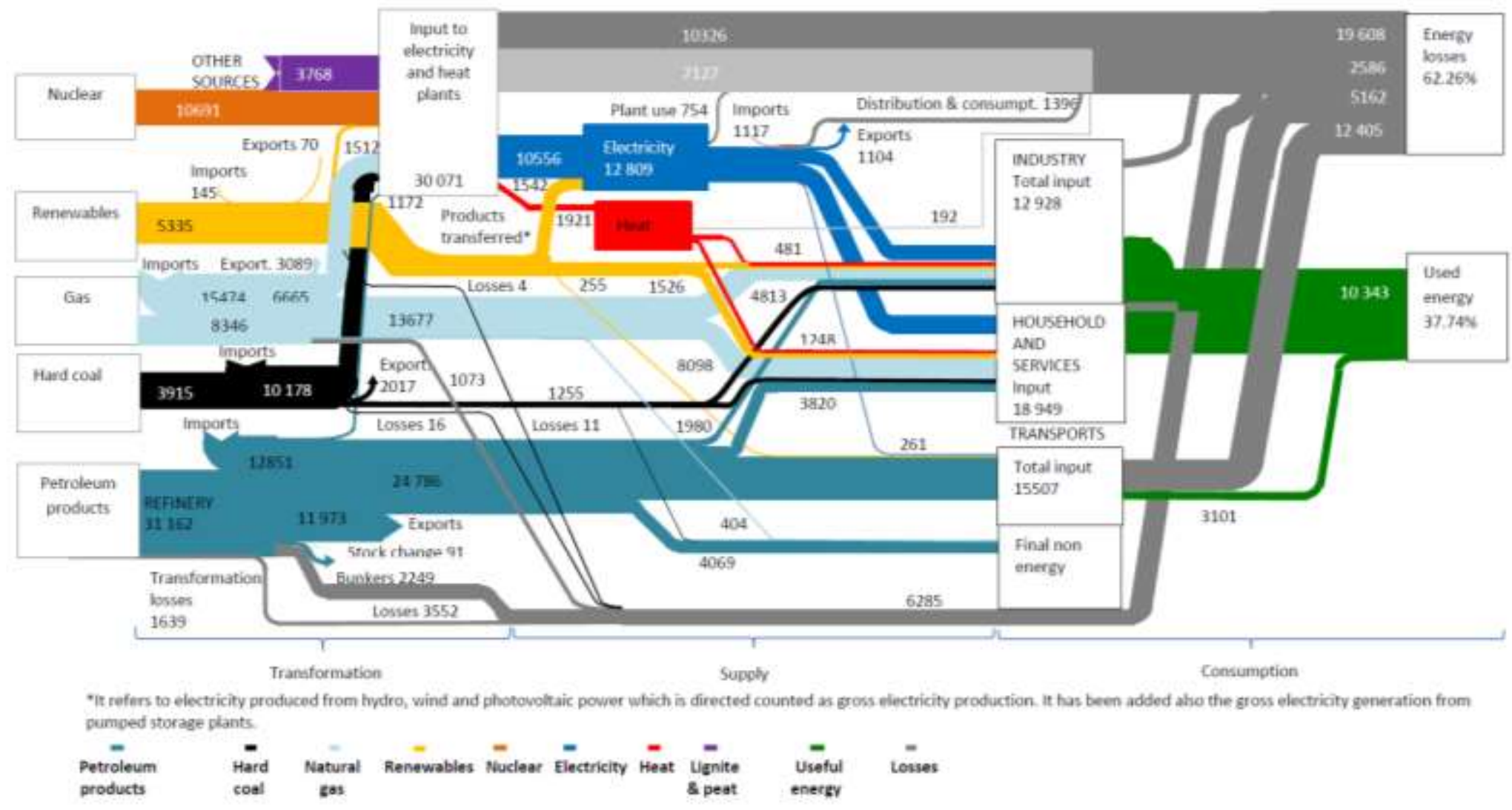

Figure 6. Sankey diagram with the EU energy balance for 2012. Source: Adapted from [4] 


\subsection{Historical of district heating prices, market share}

In (Fig. 7), the development of district heating prices for different European countries is presented from 2008 to 2012, while (Fig. 8) does the same with the percentage of users who have access to district heating networks for different countries that belong to the OECD, being of a $12.4 \%$ in 2012 for the member countries of the European Union. Finally, the contribution of cogeneration to the production of electricity for some OECD countries is presented in (Fig. 9).

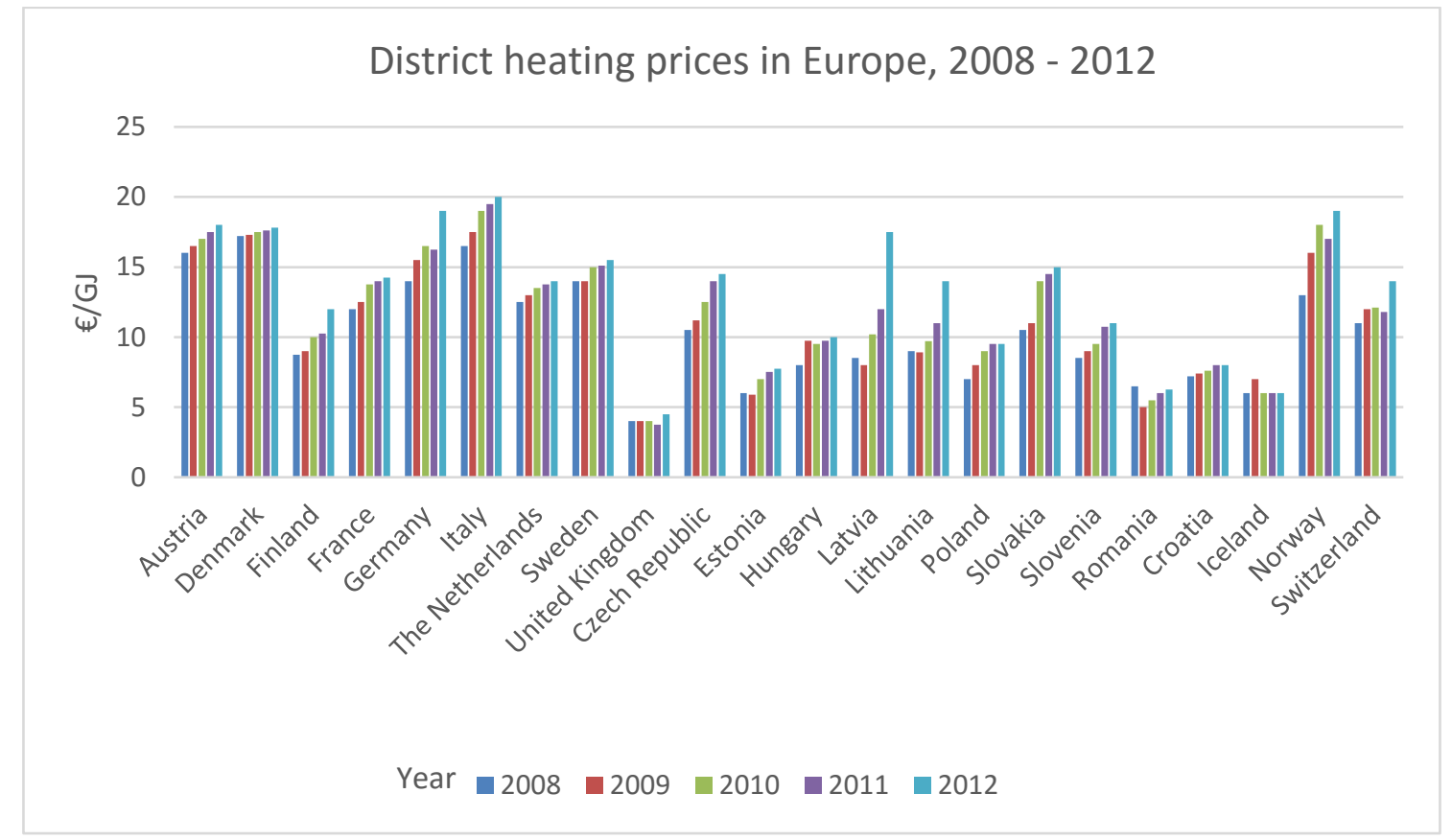

Figure 7. Price of heat supplied by district heating networks placed in Europe for the period 2008-2012 [21] 


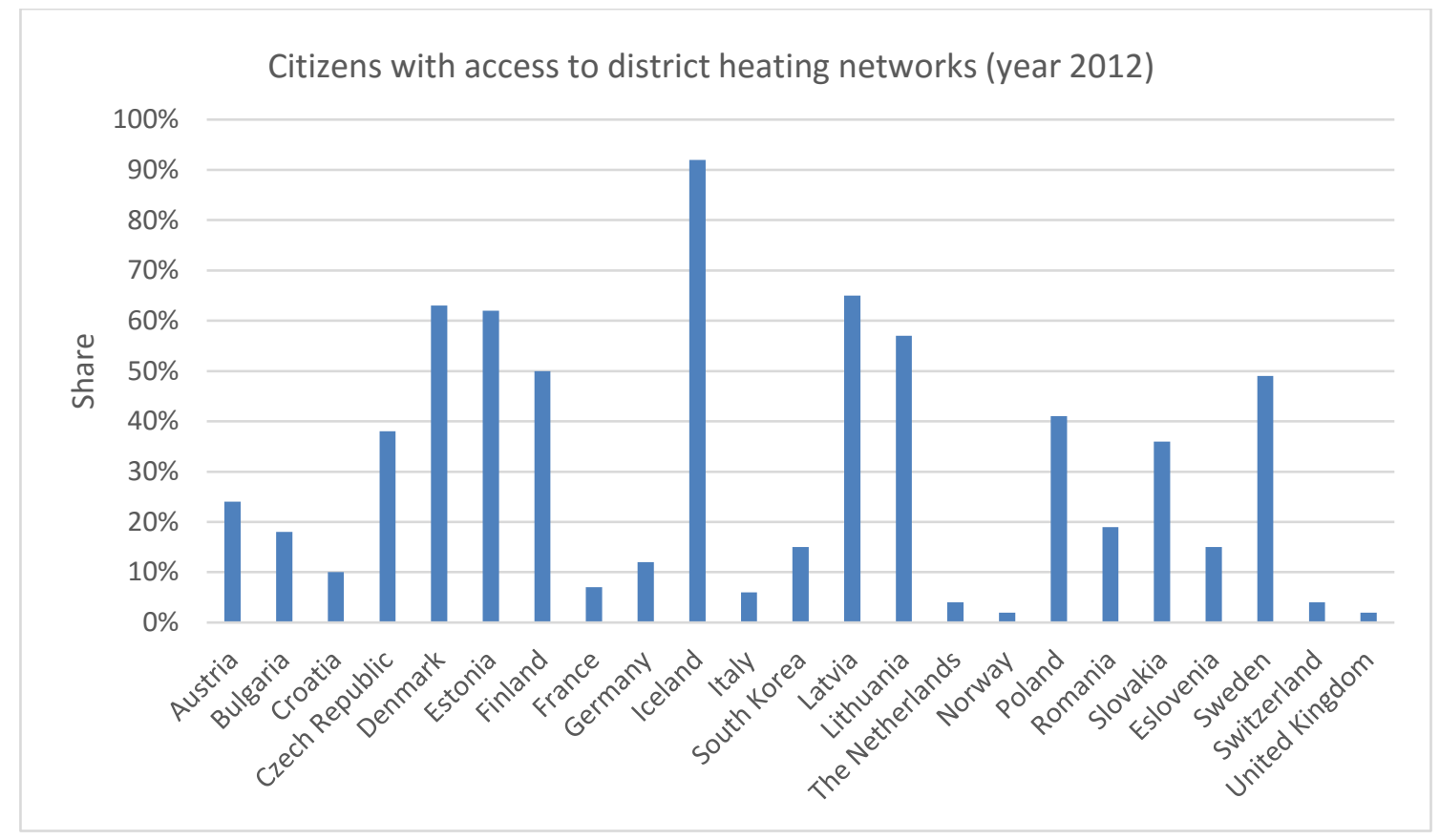

Figure 8. Percentage of citizens who have access to district heating networks for different countries of the OECD (2012) [21]

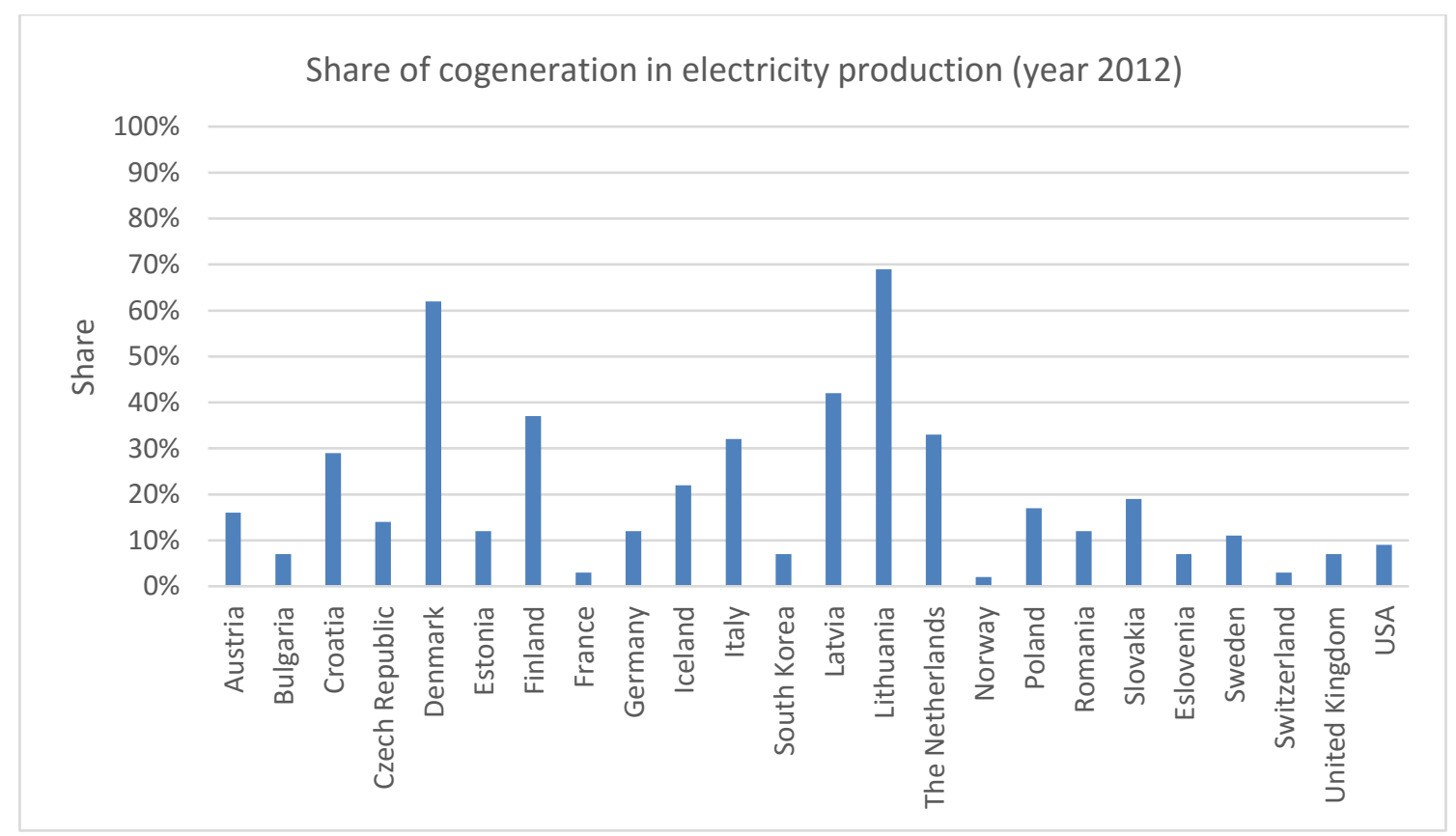

Figure 9. Contribution of CHP in electricity production for different countries of the OECD (year 2012) [21] 


\subsection{Large scale heat transport technology}

Heat transmission expenses through large-diameter pipes (even with distances being considerable) is low [22-25]. As an example, [22] shows that the cost of transmitting $2 \mathrm{GW}$ of heat through large-diameter pipes at a distance of about $140 \mathrm{~km}$ would be about $0.25 € / \mathrm{kWh}$, this being due to the fact that the ability to transport heat through the pipe is proportional to the square of the diameter, while the cost of the pipe increases proportionally with the diameter [22]. Therefore, the larger the piping and the demands of users, the greater the heat loss and the cost per unit of energy delivered (Table 2).

Table 2. Comparison of the heat transport cost depending on the diameter and length of the pipe [23]

\begin{tabular}{|c|c|c|c|c|c|c|}
\hline DN & Flow & Capacity & $\begin{array}{l}\text { Price pr. km } \\
\text { trench }\end{array}$ & Price pr. km pr. capacity & $\begin{array}{l}\text { Price pr. km pr. } \\
\text { annual sale }\end{array}$ & $\begin{array}{c}\text { Heat loss pr. } \\
\text { km }\end{array}$ \\
\hline $\mathrm{mm}$ & $\mathrm{m} / \mathrm{s}$ & MW & $\mathrm{m} \in / \mathrm{km}$ & $€ / \mathrm{km} / \mathrm{MW}$ & $€ / \mathrm{km} / \mathrm{MWh} /$ year & $\% / \mathrm{km}$ \\
\hline 100 & 1.0 & 2 & 0.6 & 274000 & 68.0 & 2.96 \\
\hline 200 & 1.5 & 13 & 1.1 & 78000 & 20.0 & 1.08 \\
\hline 300 & 2.0 & 38 & 1.7 & 45000 & 11.0 & 0.50 \\
\hline 400 & 2.3 & 69 & 2.2 & 31300 & 7.0 & 0.28 \\
\hline 500 & 2.6 & 125 & 2.8 & 22400 & 6.0 & 0.15 \\
\hline 600 & 2.9 & 203 & 3.4 & 16700 & 3.5 & 0.11 \\
\hline 700 & 3.2 & 301 & 3.9 & 12600 & 3.5 & 0.09 \\
\hline 800 & 3.5 & 431 & 4.3 & 10000 & 2.5 & 0.07 \\
\hline 900 & 3.5 & 551 & 4.9 & 9000 & 2.5 & 0.06 \\
\hline 1000 & 3.5 & 681 & 5.7 & 8200 & 2.5 & 0.05 \\
\hline \multicolumn{6}{|c|}{ Supply temperature (pre-insulated pipes) } & $120 \stackrel{\circ}{C}$ \\
\hline \multicolumn{6}{|c|}{ Return temperature (designed maximum operating temperature $=130 \stackrel{\circ}{\circ}$ ) } & $60 \stackrel{\circ}{\circ}$ \\
\hline \multicolumn{6}{|c|}{ Pressure loss (variable flow pumps) } & $10 \mathrm{~mm} / \mathrm{m}$ \\
\hline
\end{tabular}

An example of large-scale heat transport technology can be cited the case of Aarhus or that of Prague. Although the distance from the cogeneration plant to the center of the city of Aarhus is only $20 \mathrm{~km}$ [26], the total length of the heat transport network rises to $130 \mathrm{~km}$ [27], representing the total length of all pipelines that are continuously connected. In (Fig. 10), it can be observed that this large-scale heat transport network is part of a system consisting of generating plants (Studstrupvaerket), closed vessels in which water or other fluid is heated for consumption peaks, and apparatuses for burning waste material (ACA). 


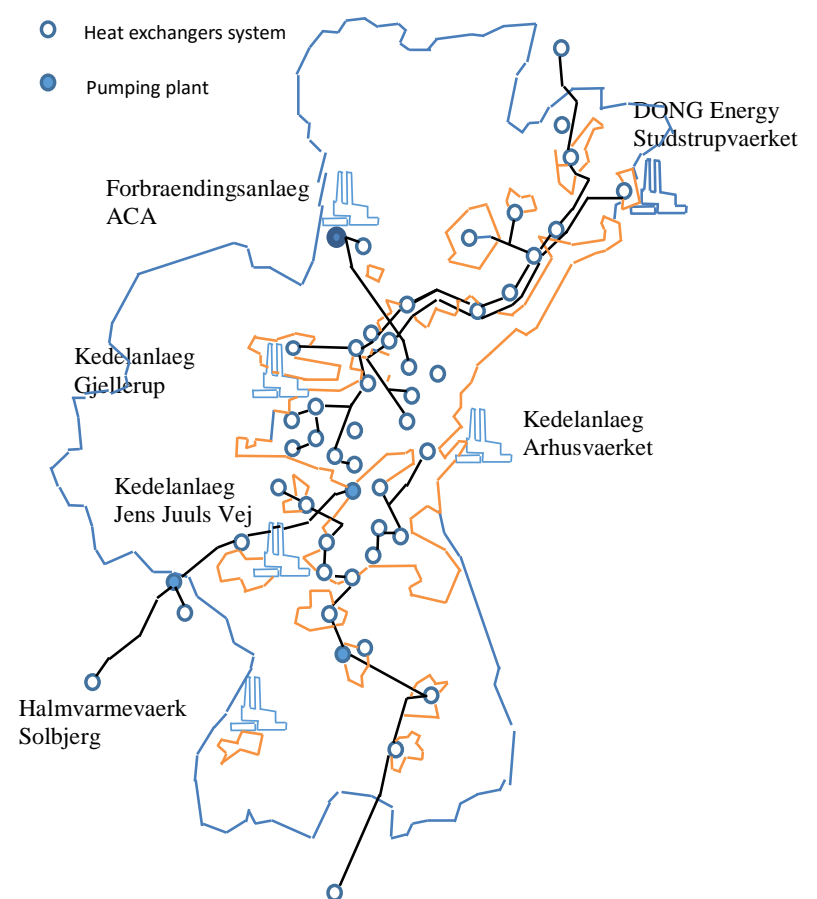

Figure 10. Heat transport system of Aarhus [28]

As for Prague, heat transport piping from the cogeneration plant of Melnik have a diameter of $1.2 \mathrm{~m}$ and a system length of $63.5 \mathrm{~km}$ [29]. As can be seen in (Fig. 11), to cover much of the distance between Melnik and Prague, pipes are laid above the surface.

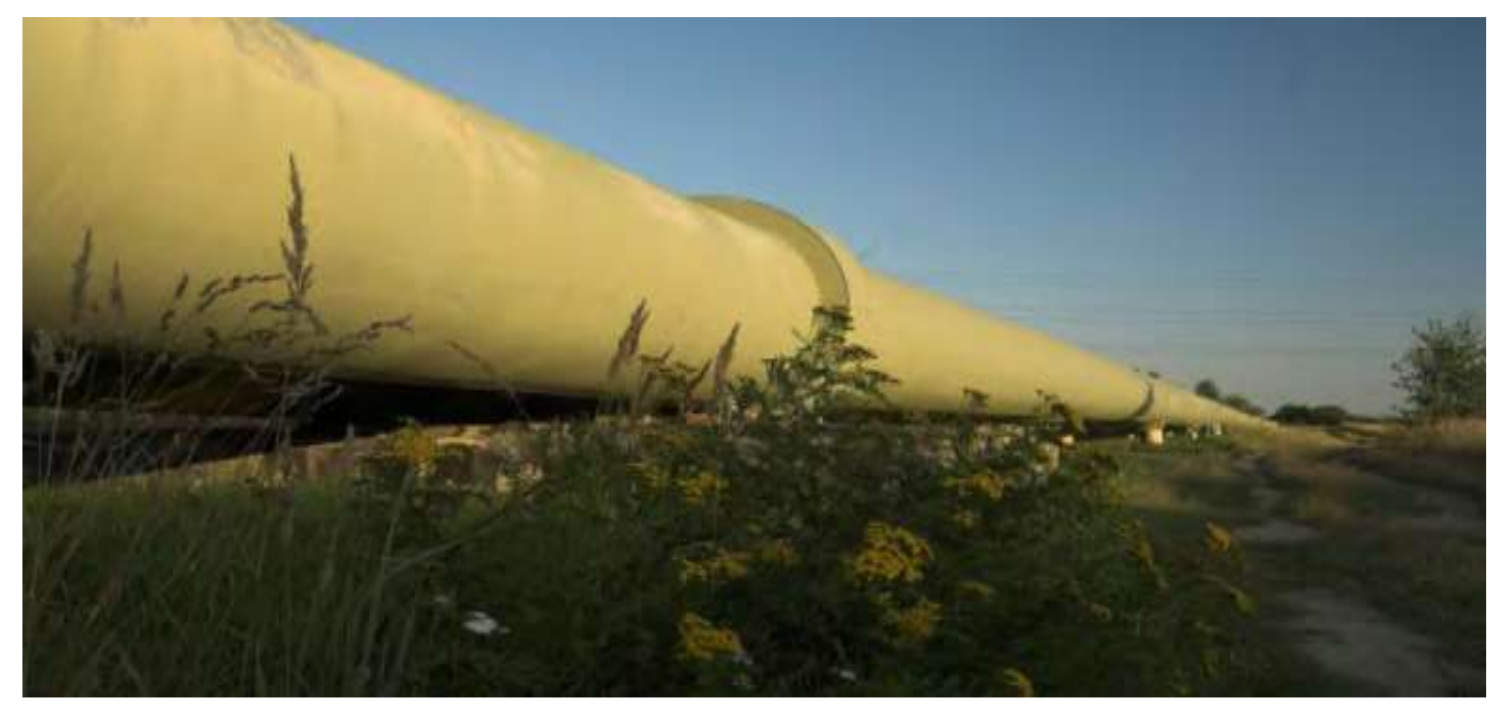

Figure 11. Pipes for transporting large-scale heat (2xDN 1200) between Melnik and Prague [30] 


\subsection{Heat distribution in modern district heating systems}

In modern systems, the heat distribution is almost always conducted through the use of preinsulated pipes that distribute hot water [31] (HWP are usually buried directly in the ground, so their installation is cheap, requiring no maintenance) [32].

Furthermore, it is noteworthy that to obtain a higher efficiency regarding electricity, heat temperature extraction should be as small as possible, being as consequences that the heat is cheaper in fuel costs and the carbon dioxide emissions are lower [33]. These are the main reasons why there is a trend towards the use of water at a lower temperature - although, in a limited number of systems, such a small temperature as $45{ }^{\circ} \mathrm{C}-55^{\circ} \mathrm{C}$ may be working properly [34], a temperature between $70^{\circ} \mathrm{C}$ and $80^{\circ} \mathrm{C}$ is a more "reasonable" one [35-37].

In some circumstances, and very especially in locations with flat terrain where district heating systems have a low-temperature design (below $90^{\circ} \mathrm{C}$ ) [38,39], a direct connection from the dwelling to the principal district heating network can be performed [37]. This approach has the advantage of the ability to use lower temperatures and provide the highest efficiency possible, thus giving lower losses per unit of heat used. With a direct connection, it is possible to eliminate the cost of any heat exchanger [37]. A valve that reduces the pressure for each consumer to prevent from overpressure to end-user facilities is used [37]. Direct connections, therefore, have many advantages because it is not necessary to allocate any investment for heat exchangers and it allows a more efficient operation of cogeneration regarding energy generation [37].

\subsection{Thermal storage in accumulators for district heating systems}

Currently, a very limited percentage of the EU-28 produced electricity is stored (predominantly in reversible hydroelectric power stations) [40,41], so any significant increase (such as by the use of wind energy for heating buildings) would be extremely costly $[42,43]$ and would involve a considerable increase in the capacity of transmission and distribution [44].

The electricity storage through isentropic heat pumps is currently the only long-term electricity technology storage that can be used in the electrical network in an economical way, having a cost of about $35 € / \mathrm{kWh}$ [45]. Meanwhile, the thermal storage is considerably cheaper as the cost varies in a band range of 0.1 and $10 € / \mathrm{kWh}$, in this case not needing any upgrading of the electricity grid [46]. Thermal storage allows the cogeneration plant to generate electricity whenever and to increase system flexibility due to the fact that thermal storage heat output change is almost immediate and that, unlike backpressure cogeneration plants that have to generate heat even when electricity price is high, condensing-extraction cogeneration plants have increased flexibility thanks to the possibility of generating electricity exclusively $[47,48]$. 
In (Fig. 12) and (Fig. 13) are respectively shown the heat storage directly and indirectly connected to the district heating network.

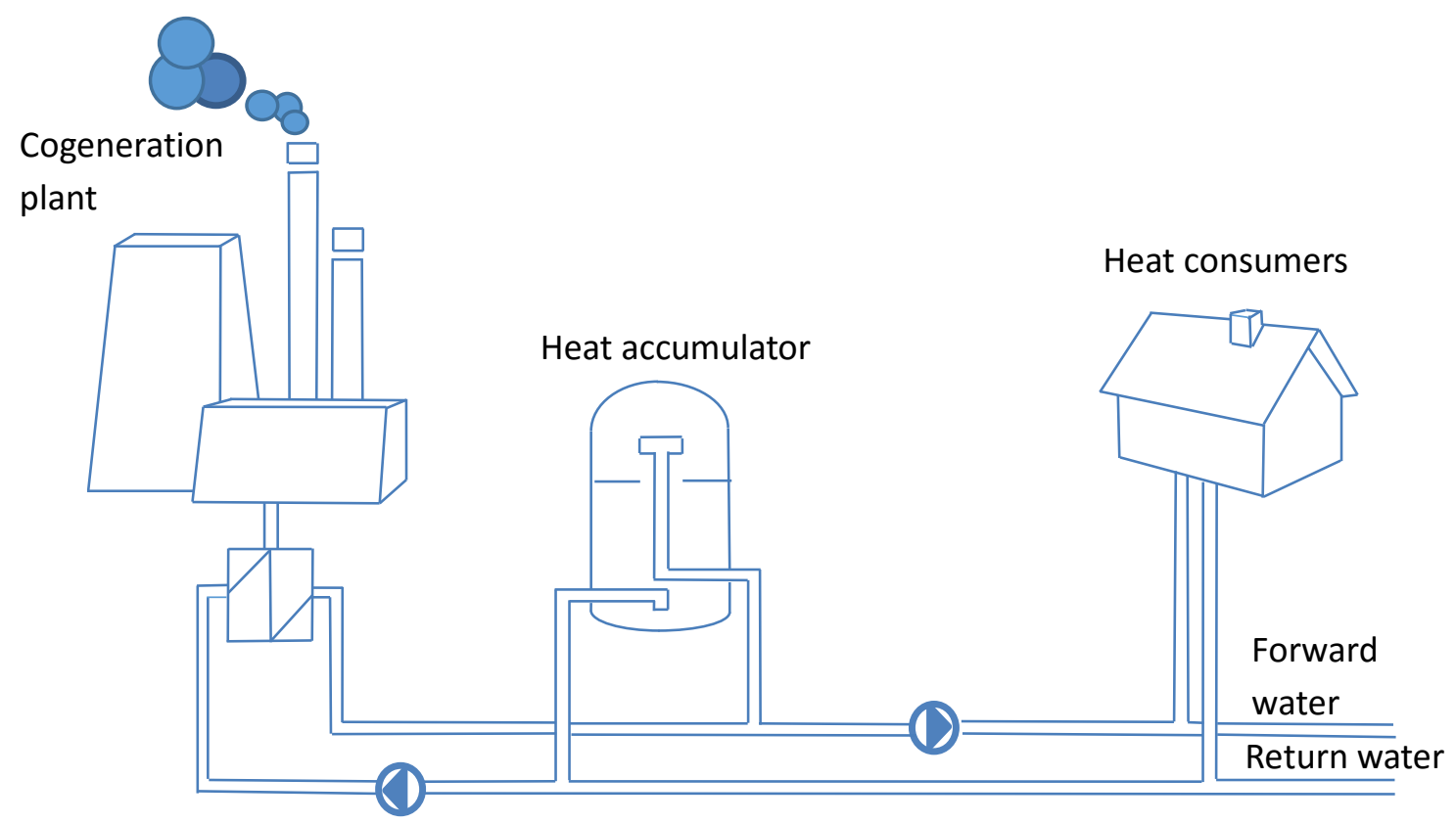

Figure 12. Thermal storage directly connected to a district heating system [49]

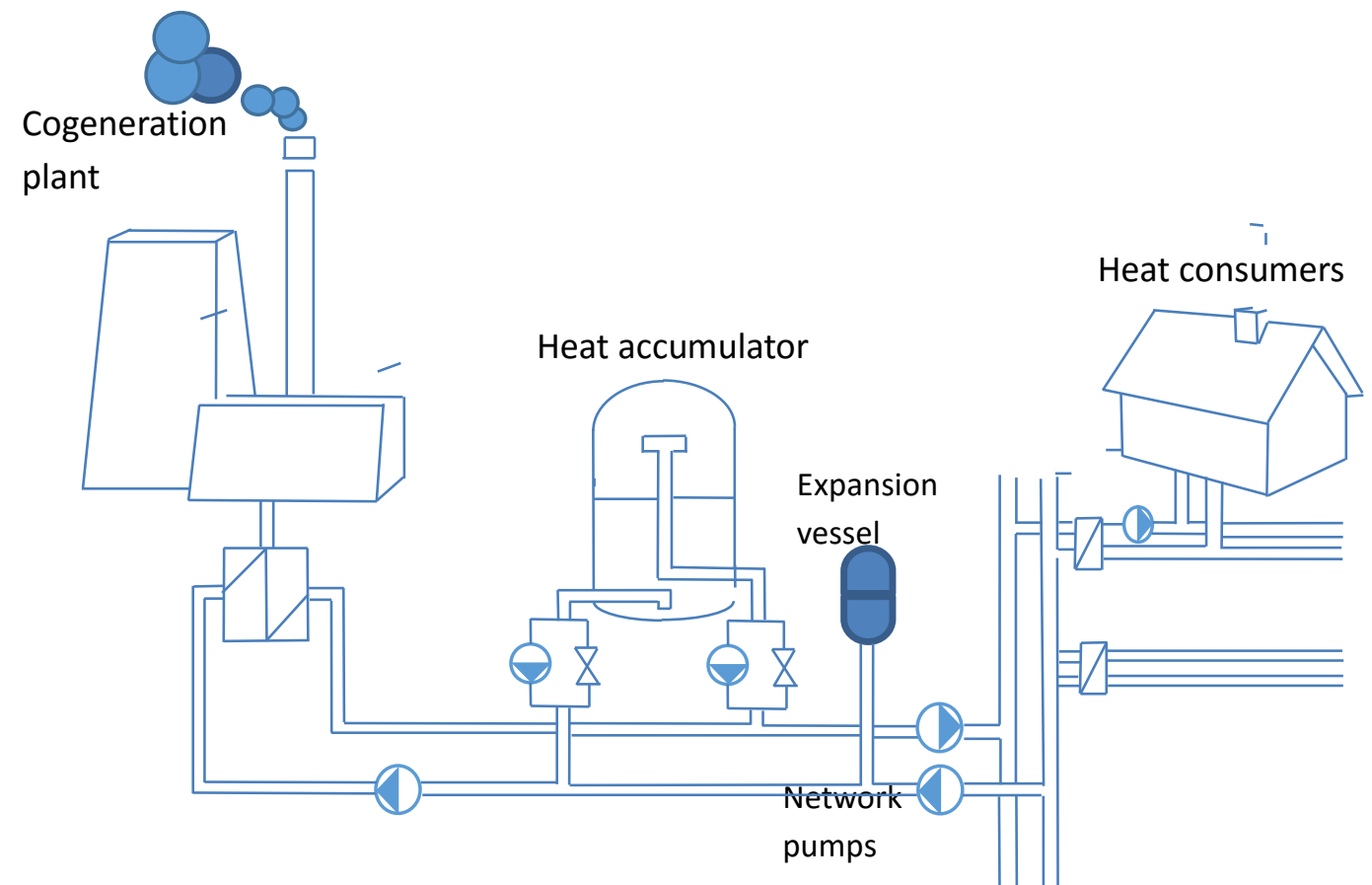

Figure 13. Accumulator with hydraulic separation from the district heating system [49] 


\subsection{Fuel used invariability and efficiency}

With the exception of those buildings with a large number of computer equipment and due to climatological reasons, domestic air conditioning, in some parts of Europe, is still being considered a luxury (meanwhile heating is seen as essential).

District cooling systems are similar to district heating networks in the sense that a fluid is distributed and conducted through tubings [50]. However, there are some major distinctions. For example, there are differences between the residential and commercial sectors, which for the latter, are dominated by district cooling networks [22]. This situation can be given the following factors:

- Air conditioning systems are profusely used in the services sector, whereas they have a limited penetration in dwellings [22].

- The size of the district cooling network is a point to be considered so that it is viable from an economic perspective [51].

- Normally, there is a refrigeration density need requirement in order to be profitable to use as a district cooling system, being compulsory that the users are located close to each other [52].

- Another factor is the limited ratio energy/liquid quantity in comparison with DHNs [53] because of the lower temperature differences. For instance, in district cooling systems, flow temperature is around $+5{ }^{\circ} \mathrm{C}$, and back temperature is $+15{ }^{\circ} \mathrm{C}$ (temperature difference of about $10^{\circ} \mathrm{C}$ ). Meanwhile, in a district heating system, flow temperature would be around $90^{\circ} \mathrm{C}$, and back temperature is around $40{ }^{\circ} \mathrm{C}$ (therefore, there is a temperature difference of about $50{ }^{\circ} \mathrm{C}$ ) $[12,53]$. This is the reason why pipes used in district cooling networks are normally higher than those used in district heating networks and thus have a higher cost (Fig. 14). 


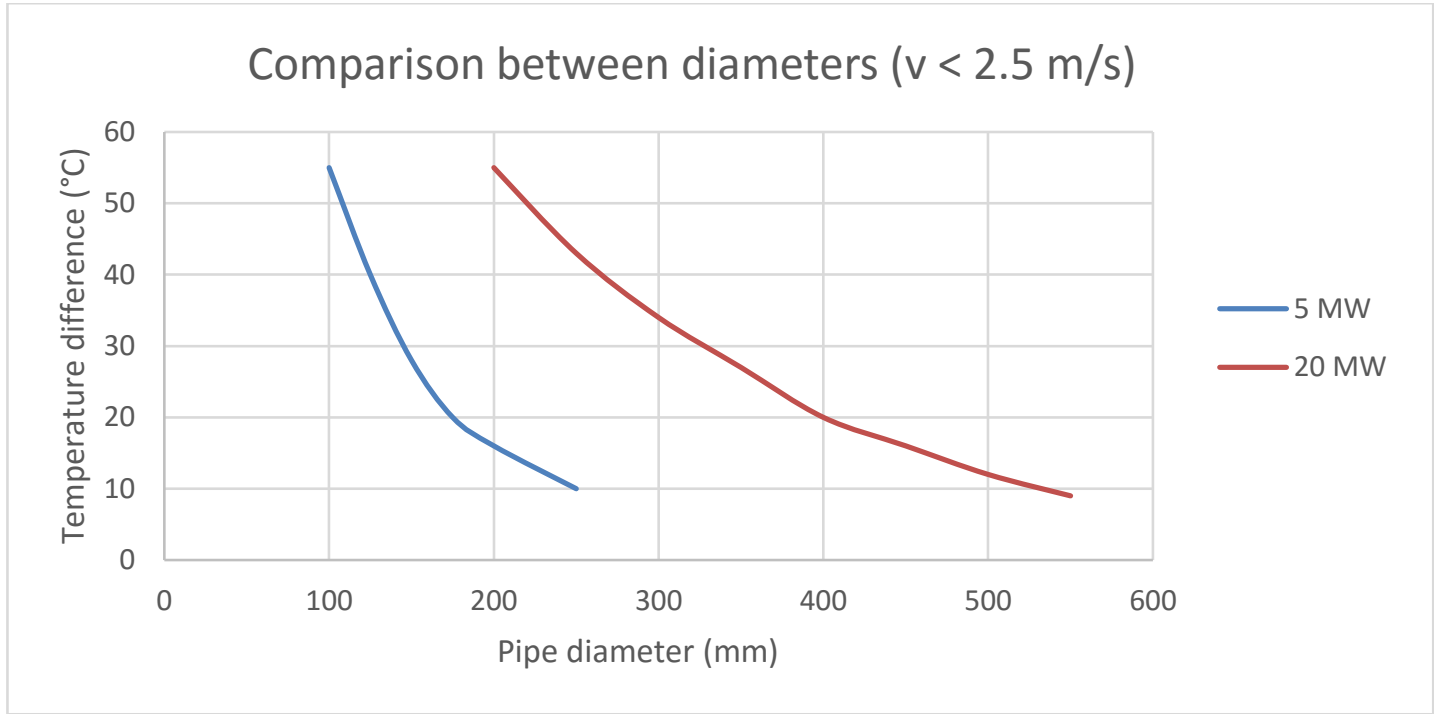

Figure 14. Comparison between the pipe diameters taking into account the differences between flow and back temperatures [53]

Most cooling applications make use of compressors driven by motors [54-57], where their coefficient of performance depends heavily on the temperature difference [58] (the better the coefficient of performance, the lower the temperature of the heat sink is) [59], as well as the type of compressor, the rating power of the cooling unit, and whether water or air is used to carry out this task [56].

For its part, the absorption chillers or the heat pumps operate under a different principle $[60,61]$. Here, instead of using the mechanical power from a motor, they make use of the heat to drive the cycle [62-65].

It should be noted that the coefficient of performance for this technology lags behind that of compressors driven by electricity $[56,66]$ and varies for commercially available lowtemperature district cooling systems from 0.65 to 1.2 [53] - that is, a unit of heat at low temperature is capable of providing between 0.65 and 1.2 units of low-temperature refrigeration depending primarily on the number of times that the heat entering the chiller is internally used [53].

Traditionally, and due to the elevated temperature's utilisation (those that occur with lowpressure steam) [67], absorption chillers lower the coefficient of performance and the refrigerating capacity greatly as the inlet temperature of the heating medium decreases (Fig. 15). This has the important effect that for a given cooling capacity, the price of the device can become excessive (Fig. 15) -nevertheless, these devices are often in district cooling systems [68]. 


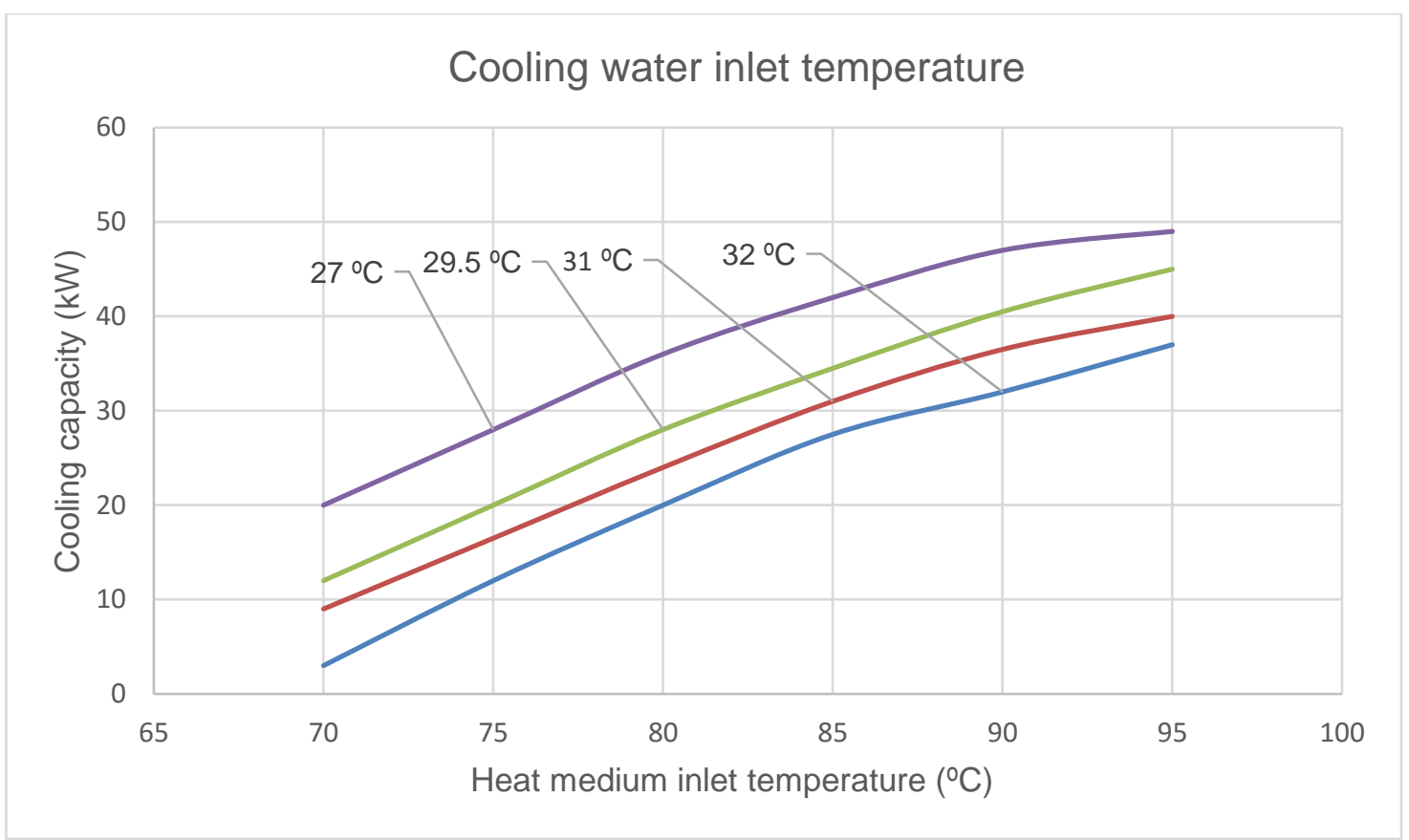

Figure 15. Cooling capacity of absorption chillers in relation to water temperature [69]

In (Fig. 16), it is shown that for 1000 hours of operation at full load, cooling costs by absorption (excluding the costs of constructing the networks) are significantly higher than the costs incurred with the technology of refrigeration through compression. 


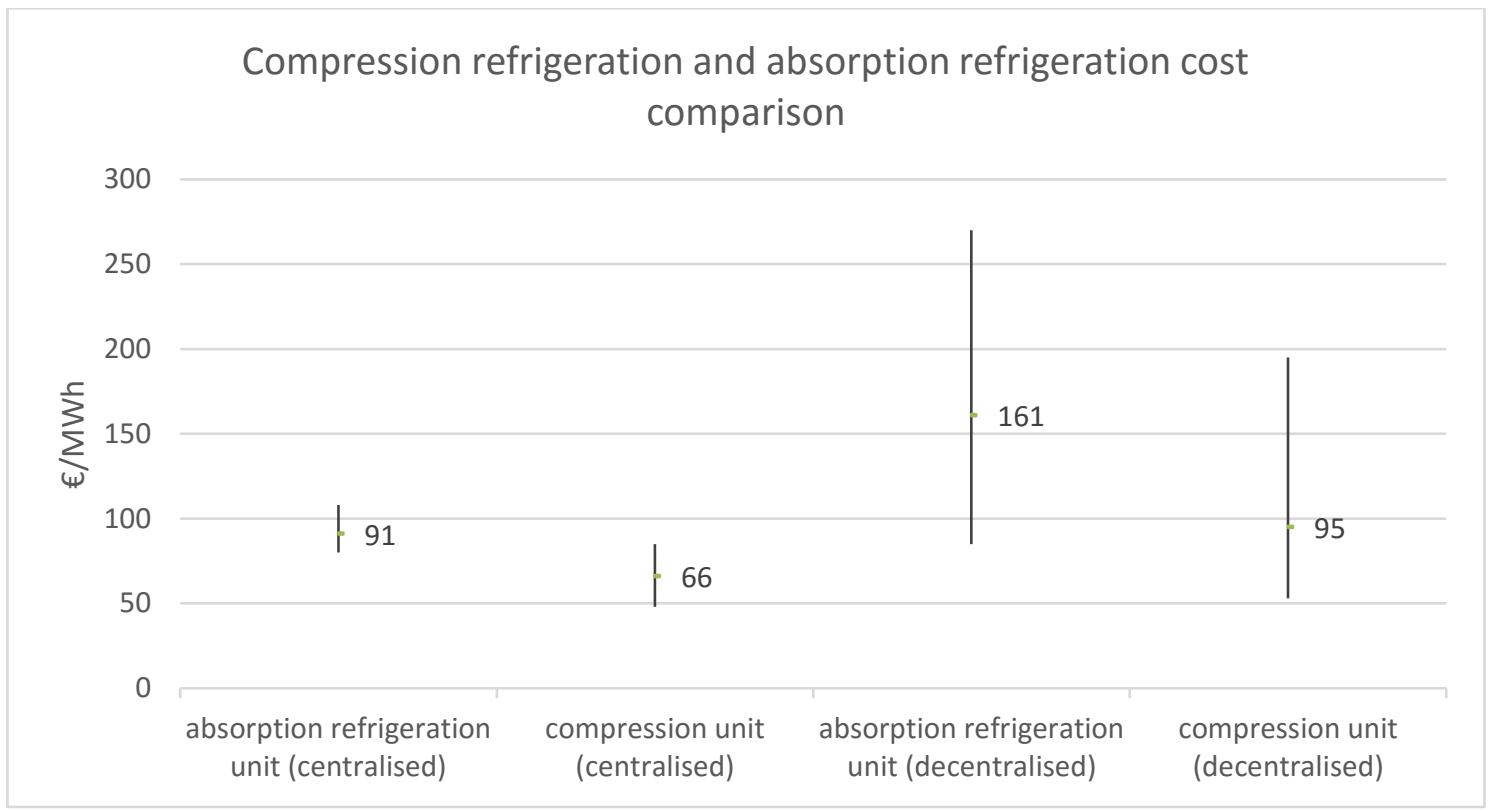

Figure 16. Comparison of refrigeration costs through compression and refrigeration through absorption (excluding construction costs of the networks) for power ranging from $300 \mathrm{~kW}$ to $500 \mathrm{~kW}$ and 1000 hours of operation at full load [70]

As it is clear from (Fig. 17) and as far as installation costs are concerned, compression refrigeration is significantly cheaper than refrigeration through absorption. However, as the installed power increases, the differences decrease considerably. 


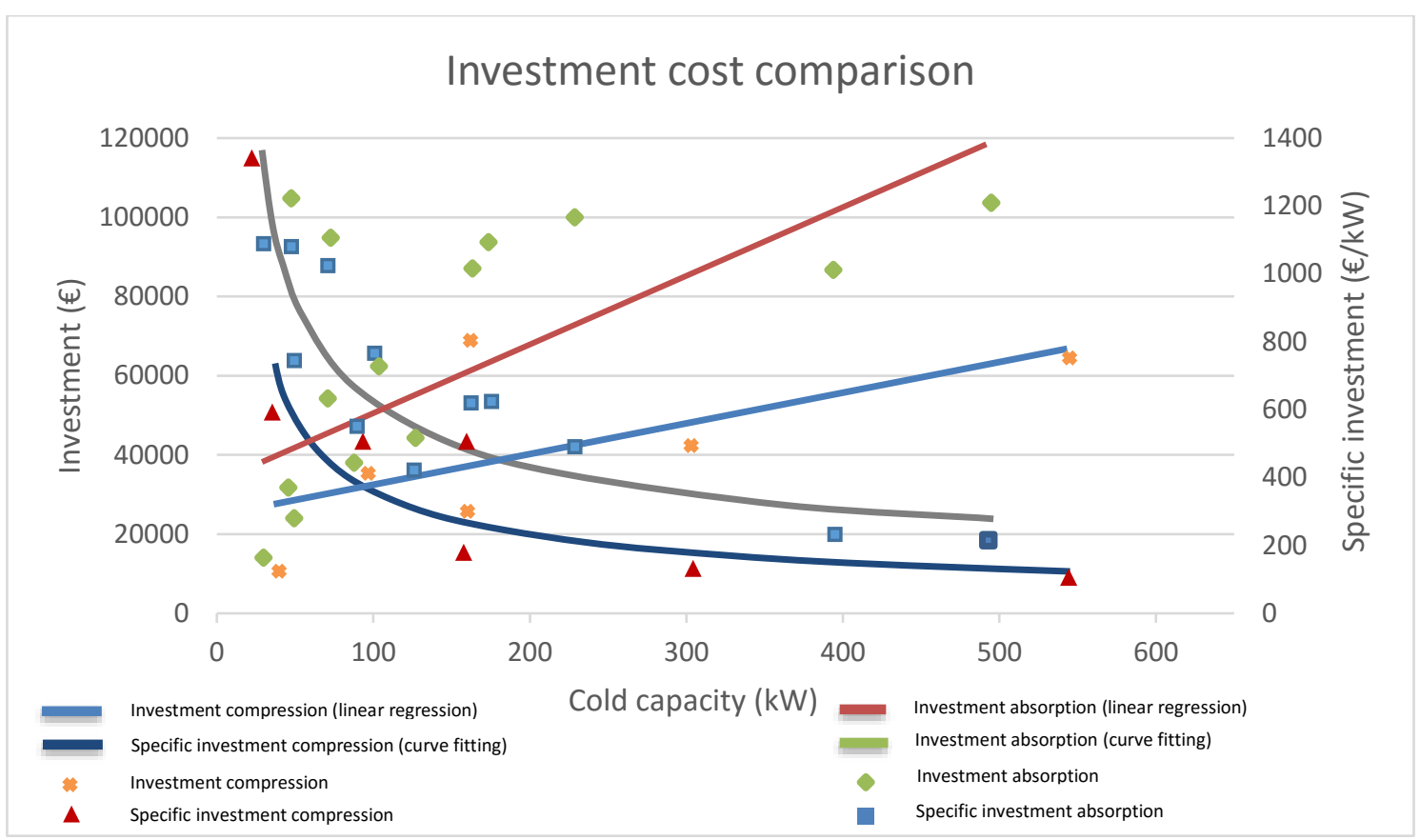

Figure 17. Comparison of the investment cost for different refrigeration machines [70]

\subsection{Fuel used invariability and efficiency}

Normally, when using cogeneration power plants and sacrificing a unit of electricity, it is possible to obtain about eight times this energy as heat (in contrast, for example, when using a heat pump, it would only be possible to get that amount multiplied by three) [7174]. When a plant starts operating as a cogeneration plant and its electricity production falls, another condensation plant which is not operating at maximum output will be responsible for increasing the power in order to compensate for this change, thus resulting in a modification of fuel consumption [75]. By definition, marginal power plants are the ones that dictate the price in every hour to all technologies [76] and, in this case, combustible used to generate electricity will remain constant [77] and at a constant efficiency [78].

\subsection{Cogeneration, district heating networks and smart cities: The case of Copenhagen}

The European Commission's "Smart Cities and Communities" initiative has already expressed in the "Strategic Energy Technology Plan" (SET-Plan) an interest in positioning a number of cities at the forefront of combating and minimising $\mathrm{CO}_{2}$ emissions [79,80]. 
District heating and cooling networks will be smarter as they make the electric grid smarter $[81,82]$. Consequently, it will be especially important that the heating and cooling have heat reservoirs $[83,84]$ so that the electric grid reacts quickly to price signals and can stabilise itself when there are fluctuating renewable energy sources. In Denmark, heating networks are the backbone of the energy system, providing enough flexibility to integrate renewable energies (especially wind) into the electric grid in a safe way [85]. One of the objectives of the EU-28 regarding energy is precisely to make these smart cities adopt the Danish energy strategy [86,87].

Renewable energy can generate electricity when prices in the electricity market are high, and even though it continues to produce electricity at night when demand is low, the stored heat may cover peak consumption that occurs during the morning. With respect to the loads of heating/cooling, district heating networks and intelligent cooling contribute to smoothing heating and cooling peak demand, thereby reducing peak production [88].

Undoubtedly, Copenhagen is the world region that more has managed to integrate electricity, district heating networks, natural gas, and waste management. Among its highlights may be mentioned the following:

- $98 \%$ of the population of Copenhagen is, in those areas where this infrastructure is present, connected to district heating networks [89].

- LAs have developed heating plans for the entire region, dividing the areas by optimal technologies, taking into account economic criteria established at a national level by the Energy Authority [90-92].

- Municipalities have created companies with a municipal participation (CTR and VEKS) to develop the heat transport system, while companies entirely belonging to the municipality are in charge of distributing this heat.

- For its part, the waste management company (Vestforbrænding) is in charge, apart from the recycling, of treating the waste produced by 20 municipalities [93] to an optimum level to introduce cogeneration in large incineration plants to ensure that all the material that cannot be recycled is used as energy.

In Denmark, the providing of the service of district heating depends on companies that are themselves local monopolies, and that typically have the necessary infrastructure for the generation, supply and sale of heat to the end user [94]. In contrast to the companies supplying gas and electricity, for these local monopolies, any benefit from the sale of heat will not be permitted to be obtained [94]. This means that only the necessary costs of construction, operation, and maintenance of district heating networks can finally be included in the fees [95]. 
To get a visual idea of how the system of generation and heat transport of the city of Copenhagen is, in (Fig. 18) a map depicting the generation and transmission system operated by VEKS, CTR, and Vestforbraendings is shown.

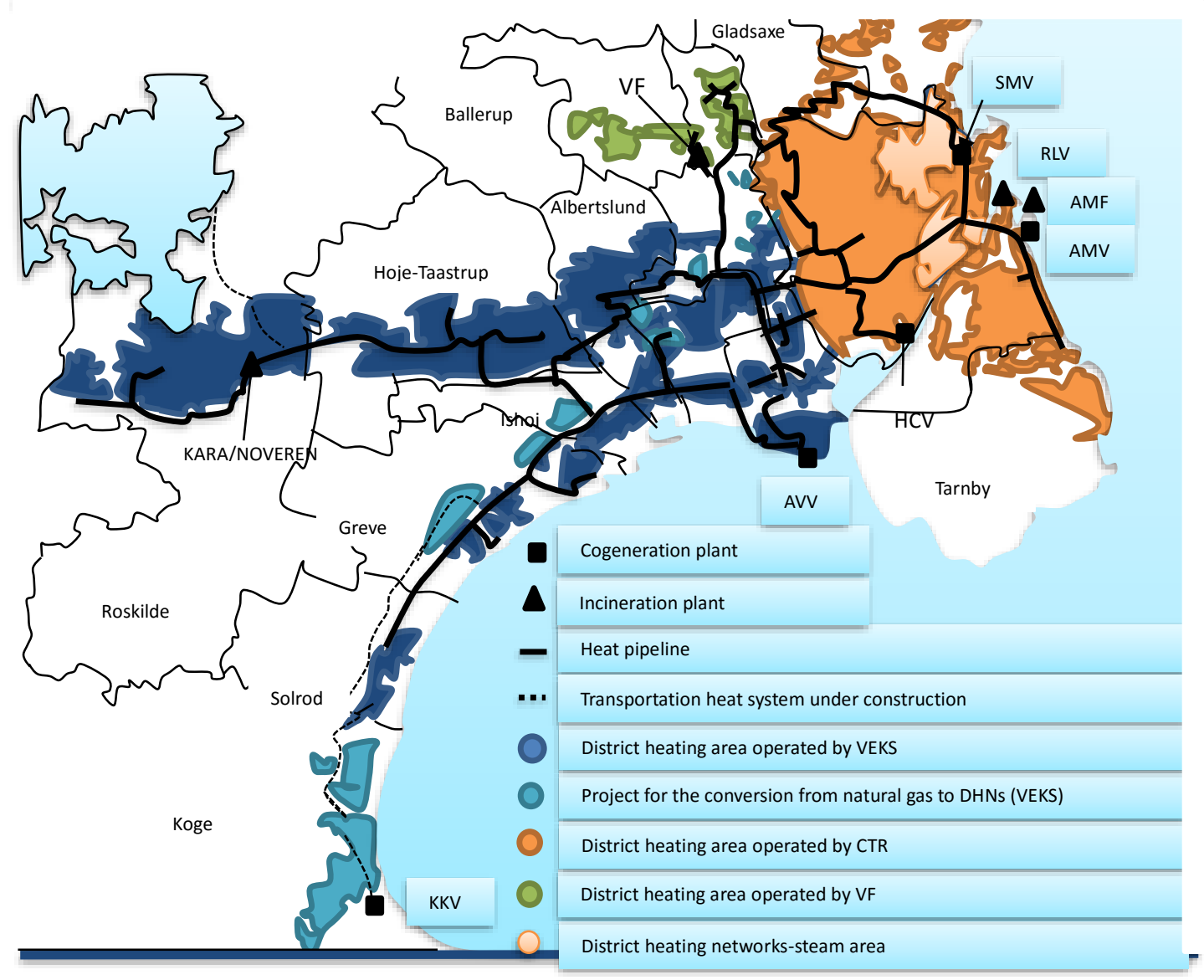

Figure 18. Map from VEKS showing the heating system in Copenhagen (only local heating systems in the area of VEKS are presented) [96]

\section{Results}

Given its economic and environmental benefits, the joint use of cogeneration and district heating networks should experience significant growth in coming years (Fig. 19) [97]. For district heating networks to achieve a penetration of over $90 \%$ in a big city, several decades may elapse, in the case of Copenhagen, it took more than 40 years [98], depending largely on the commitment of the authorities [99]. Theoretical Background section includes additional information concerning the case of Copenhagen. Note that the actions to take 
for the widespread introduction of district heating networks from the market entry stage (going through the market penetration phase) to the stage of market maturity will depend, in any case, on the casuistry of each location; therefore, an adaptation of the measures to be taken depending on specific circumstances will be necessary.

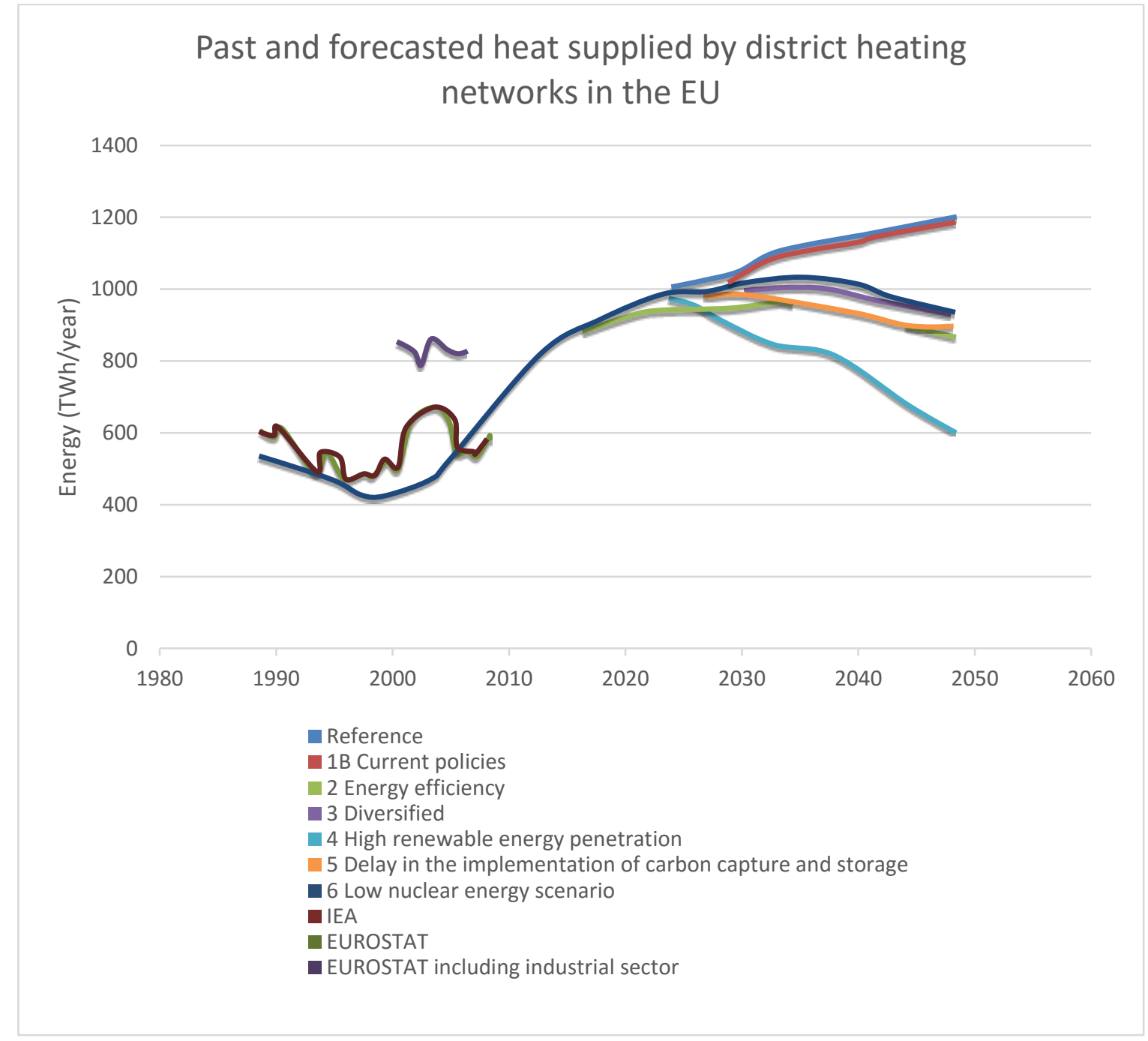

Figure 19. Different scenarios for the heat supplied by district heating networks and cogeneration plants located in the EU until 2050 [97]

To know the potential costs and energy savings, it has been supposed as a target that $50 \%$ of all domestic and commercial heating loads from the EU-28 can be satisfied from waste heat from conventional power stations and district heating networks. These results are compared country by country assuming power plants are converted into cogeneration plants. 
The estimate has been made as follows:

1. Table 3 gives the total installed capacity of thermal power plants using fossil fuels by member state in column A.

2. Column B shows the total installed capacity of cogeneration per member state (Table 3).

3. Column $\mathrm{C}$ presents the combined heat and power (electrical) generation percentage from each member state (Table 3).

4. Column D (Table 3) shows the installable capacity in the EU-28, assuming that $100 \%$ of conventional thermal power plants that use fossil fuels are converted into cogeneration plants (although not all the heat is used because the heat generated is higher than the actual demand).

Table 3. Installed capacity per member state to achieve full conversion of conventional thermal power plants in cogeneration plants. Source: Adapted from [100,101]

\begin{tabular}{|c|c|c|c|c|}
\hline & A & B & C & D \\
\hline & $\begin{array}{l}\text { Total conventional thermal } \\
\text { combustion capacity [100] } \\
\text { (GW) }\end{array}$ & $\begin{array}{l}\text { CHP electrical } \\
\text { capacity [101] } \\
\text { (GW) }\end{array}$ & $\begin{array}{l}\text { Share of CHP in electricity } \\
\text { production [101] }\end{array}$ & $\begin{array}{l}\text { Maximum } \\
\text { conversion of } \\
\text { CHP (GW) }\end{array}$ \\
\hline & 2013 & 2013 & 2013 & Vision \\
\hline AT - Austria & 6.3 & 4.4 & $14.4 \%$ & 1.9 \\
\hline BE - Belgium & 7.6 & 2.3 & $15.2 \%$ & 5.3 \\
\hline BG - Bulgaria & 4.6 & 1.2 & $8.5 \%$ & 3.4 \\
\hline CY - Cyprus & 1.6 & 0.0 & $1.4 \%$ & 1.6 \\
\hline $\begin{array}{l}\text { CZ - Czech } \\
\text { Republic }\end{array}$ & 10.5 & 4.6 & $13.7 \%$ & 5.9 \\
\hline DE - Germany & 82.0 & 27.0 & $12.4 \%$ & 55.0 \\
\hline DK - Denmark & 7.6 & 5.7 & $50.6 \%$ & 1.9 \\
\hline EE - Estonia & 2.6 & 0.5 & $9.3 \%$ & 2.1 \\
\hline ES - Spain & 49.8 & 4.0 & $8.5 \%$ & 45.8 \\
\hline FI - Finland & 8.4 & 6.3 & $34.5 \%$ & 2.1 \\
\hline FR - France & 23.0 & 5.5 & $2.4 \%$ & 17.5 \\
\hline GR - Greece & 10.7 & 0.6 & $3.4 \%$ & 10.1 \\
\hline HU - Hungary & 5.8 & 1.6 & $13.4 \%$ & 4.2 \\
\hline
\end{tabular}




\begin{tabular}{|c|c|c|c|c|}
\hline HR - Croatia & 1.7 & 0.7 & $12.6 \%$ & 1.0 \\
\hline IE - Ireland & 6.0 & 0.3 & $7.8 \%$ & 5.7 \\
\hline IT - Italy & 70.6 & 7.6 & $12.7 \%$ & 63.0 \\
\hline LT - Lithuania & 2.8 & 1.2 & $35.0 \%$ & 1.6 \\
\hline LU - Luxembourg & 0.5 & 0.5 & $14.7 \%$ & 0.0 \\
\hline LV - Latvia & 1.2 & 1.0 & $38.3 \%$ & 0.2 \\
\hline MT - Malta & 0.6 & 0.0 & $0.0 \%$ & 0.6 \\
\hline NL - Netherlands & 21.4 & 9.2 & $34.5 \%$ & 12.2 \\
\hline PL - Poland & 28.2 & 8.3 & $15.9 \%$ & 19.9 \\
\hline PT - Portugal & 6.4 & 1.4 & $13.8 \%$ & 5.0 \\
\hline RO - Romania & 9.0 & 2.2 & $11.2 \%$ & 6.8 \\
\hline SE - Sweden & 6.6 & 4.5 & $10.2 \%$ & 2.1 \\
\hline SI - Slovenia & 1.2 & 0.3 & $7.1 \%$ & 0.9 \\
\hline SK - Slovakia & 2.8 & 4.4 & $77.0 \%$ & 0.0 \\
\hline $\begin{array}{l}\text { UK } \\
\text { Kingdom }\end{array}$ & 59.0 & 6.2 & $5.5 \%$ & 52.8 \\
\hline EU-28 & 438.5 & 111.5 & & 328.6 \\
\hline
\end{tabular}

Column E (Table 4) represents the additional energy obtained from converting all conventional power plants placed in the EU-28 into cogeneration plants, as shown in column D (Table 3). It is supposed that once the conventional thermal power plant has been converted, LF is 0.6 . HPR calculations were carried out, taking into account columns A and B (Table 4), which correspond to the statistics available from EUROSTAT for the main power producers and not for the one of the auto-producers, and assuming that the heat of a CHP plant will feed district heating networks. 
Table 4. Calculation of the annual heat obtained from the conversion of conventional thermal power plants located in the EU-28. Source: Adapted from [101]

\begin{tabular}{|c|c|c|c|c|c|}
\hline & A & B & C & D & E \\
\hline & $\begin{array}{c}\text { Electricity } \\
\text { generation from } \\
\text { CHP plants [101] } \\
\text { (TWh) }\end{array}$ & $\begin{array}{c}\text { Heat generation } \\
\text { from CHP plants } \\
\text { [101] (TWh) }\end{array}$ & $\begin{array}{l}\text { Heat to power } \\
\text { ratio }\end{array}$ & $\begin{array}{c}\text { Maximum } \\
\text { conversion of CHP } \\
(G W)\end{array}$ & $\begin{array}{l}\text { Maximum } \\
\text { annual } \\
\text { additional } \\
\text { heat output } \\
\text { (TWh) }\end{array}$ \\
\hline & 2013 & 2013 & 2013 & Vision & Vision \\
\hline AT - Austria & 9.9 & 30.8 & 3.1 & 1.9 & 31.0 \\
\hline BE - Belgium & 12.7 & 7.6 & 0.6 & 5.3 & 16.7 \\
\hline BG - Bulgaria & 3.7 & 11.2 & 3.0 & 3.4 & 53.6 \\
\hline CY - Cyprus & 0.1 & 0.0 & I & 1.6 & 8.4 \\
\hline $\begin{array}{l}\text { CZ - Czech } \\
\text { Republic }\end{array}$ & 12.0 & 33.6 & 2.8 & 5.9 & 86.8 \\
\hline DE - Germany & 78.7 & 181.7 & 2.3 & 55.0 & 664.9 \\
\hline DK - Denmark & 17.6 & 28.7 & 1.6 & 1.9 & 16.0 \\
\hline EE - Estonia & 1.2 & 3.5 & 2.9 & 2.1 & 32.0 \\
\hline ES - Spain & 24.1 & 48.6 & 2.0 & 45.8 & 481.4 \\
\hline FI - Finland & 24.3 & 69.8 & 2.9 & 2.1 & 32.0 \\
\hline FR - France & 14.0 & 41.8 & 3.0 & 17.5 & 275.9 \\
\hline GR - Greece & 2.0 & 2.9 & 1.5 & 10.1 & 79.6 \\
\hline HU - Hungary & 3.9 & 7.5 & 1.9 & 4.2 & 41.9 \\
\hline HR - Croatia & 1.7 & 3.7 & 2.2 & 1.0 & 11.6 \\
\hline IE - Ireland & 2.0 & 3.4 & 1.7 & 5.7 & 51.0 \\
\hline IT - Italy & 36.7 & 59.1 & 1.6 & 63.0 & 529.8 \\
\hline LT - Lithuania & 1.7 & 4.3 & 2.5 & 1.6 & 21.0 \\
\hline LU - Luxembourg & 0.4 & 0.9 & 2.3 & 0.0 & 0.0 \\
\hline LV - Latvia & 2.4 & 3.1 & 1.3 & 0.2 & 1.4 \\
\hline MT - Malta & 0.0 & 0.0 & I & 0.6 & 3.2 \\
\hline NL - Netherlands & 34.8 & 60.5 & 1.4 & 12.2 & 89.8 \\
\hline
\end{tabular}




\begin{tabular}{|c|c|c|c|c|c|}
\hline PL - Poland & 26.1 & 71.5 & 2.7 & 19.9 & 282.4 \\
\hline PT - Portugal & 7.2 & 19.0 & 2.6 & 5.0 & 68.3 \\
\hline RO - Romania & 6.6 & 16.1 & 2.4 & 6.8 & 85.8 \\
\hline SE - Sweden & 15.6 & 45.9 & 2.9 & 2.1 & 32.0 \\
\hline SI - Slovenia & 1.2 & 3.0 & 2.5 & 0.9 & 11.8 \\
\hline SK - Slovakia & 22.2 & 7.7 & 0.3 & 0.0 & 0.0 \\
\hline $\begin{array}{l}\text { UK } \\
\text { Kingdom }\end{array}$ & 19.7 & 39.6 & 2.0 & 52.8 & 555.0 \\
\hline EU-28 & 390.1 & 789.4 & I & 328.6 & 3563.3 \\
\hline
\end{tabular}

We have proceeded in this way due to the fact that:

1. the vast majority of non-cogeneration thermal power plants belong to large power producers and not to auto-producers

2. and that the uncertainty of connecting the waste heat from a power plant to a district heating network is much lower than the one that would be obtained if industrial waste heat were to be used, where other factors, such as the possibility that a given industry remains at least 60 years working in a given location, should be evaluated.

Because district heating networks always will have availability restrictions, this paper has centered on HHW requirements for tertiary and residential sectors. An analysis of the technical potential of the district heating networks is shown in (Table 5). As indicated earlier in this section, it has been assumed that district heating networks can supply roughly $50 \%$ of all heating requirements, domestic and commercial ones. In (Table 5), it is possible to see that it has been supposed that the potential feasible for district heating networks (column $\mathrm{E}$ ) is $50 \%$ of the maximum theoretical heat, a scenario in which all domestic and commercial loads have access and are satisfied through district heating networks (column C). 
Table 5. Analysis of the technical potential of district heating networks. Source: Adapted from $[2,11,102,103]$

\begin{tabular}{|c|c|c|c|c|c|c|c|}
\hline & A & B & C & D & $\mathbf{E}$ & $\mathbf{F}$ & G \\
\hline & $\begin{array}{c}\text { Final total } \\
\text { energy } \\
\text { consumption } \\
\text { [2] (PJ) }\end{array}$ & $\begin{array}{c}\text { Total district } \\
\text { heating } \\
\text { networks sales } \\
{[102](\mathrm{PJ})}\end{array}$ & $\begin{array}{c}\text { Percentage of } \\
\text { citizens served } \\
\text { by district } \\
\text { heating } \\
{[102,103]}\end{array}$ & $\begin{array}{c}\text { Maximum } \\
\text { annual } \\
\text { additional } \\
\text { heat }(\mathrm{PJ})\end{array}$ & $\begin{array}{l}\text { DHNs feasible } \\
\text { potential (PJ) }\end{array}$ & Region & $\begin{array}{l}\text { Conversion cost } \\
+ \text { DHNs cost [11] } \\
\text { (annual cost of } \\
\text { investment in } \\
\text { milliards of } € \text { ) }\end{array}$ \\
\hline & 2013 & 2013 & 2013 & Vision & Vision & & Vision \\
\hline AT - Austria & 1170.2 & 80.7 & $24 \%$ & 111.6 & 55.8 & $\mathrm{~N}-\mathrm{C}$ & 2.4 \\
\hline BE - Belgium & 1457.1 & 21.0 & $3 \%$ & 60.1 & 30.1 & $\mathrm{~N}-\mathrm{C}$ & 1.4 \\
\hline BG - Bulgaria & 367.2 & 18.0 & $18 \%$ & 193.0 & 96.5 & $\mathrm{~N}-\mathrm{C}$ & 4.2 \\
\hline CY - Cyprus & 67.6 & 0.0 & $0 \%$ & 30.2 & 15.1 & $S$ & 1.0 \\
\hline $\begin{array}{l}\text { CZ - Czech } \\
\text { Republic }\end{array}$ & 1000.0 & 89.4 & $38 \%$ & 312.5 & 156.3 & $\mathrm{~N}-\mathrm{C}$ & 6.8 \\
\hline DE - Germany & 9096.0 & 254.8 & $12 \%$ & 2393.6 & 1196.8 & $\mathrm{~N}-\mathrm{C}$ & 52.6 \\
\hline DK - Denmark & 594.3 & 105.5 & $63 \%$ & 57.6 & 28.8 & $\mathrm{~N}-\mathrm{C}$ & 1.4 \\
\hline EE - Estonia & 120.2 & 23.0 & $62 \%$ & 115.2 & 57.6 & $\mathrm{~N}-\mathrm{C}$ & 2.6 \\
\hline ES - Spain & 3397.0 & 0.0 & $0 \%$ & 1733.0 & 866.5 & $S$ & 52 \\
\hline FI - Finland & 1030.6 & 114.2 & $50 \%$ & 115.2 & 57.6 & $\mathrm{~N}-\mathrm{C}$ & 2.6 \\
\hline FR - France & 6366.3 & 96.1 & $7 \%$ & 993.2 & 496.6 & $\mathrm{~N}-\mathrm{C}$ & 20.2 \\
\hline GR - Greece & 642.2 & 1.0 & $0 \%$ & 286.6 & 143.3 & $S$ & 8.6 \\
\hline HU - Hungary & 628.8 & 31.0 & $15 \%$ & 150.8 & 75.4 & $\mathrm{~N}-\mathrm{C}$ & 3.4 \\
\hline HR - Croatia & 243.4 & 9.7 & $10 \%$ & 41.8 & 20.9 & $\mathrm{~N}-\mathrm{C}$ & 1.0 \\
\hline IE - Ireland & 449.6 & 0.1 & $0 \%$ & 183.6 & 91.8 & $\mathrm{~N}-\mathrm{C}$ & 4.0 \\
\hline IT - Italy & 4969.6 & 33.1 & $6 \%$ & 1907.3 & 953.7 & $S$ & 57.2 \\
\hline LT - Lithuania & 198.3 & 27.1 & $57 \%$ & 75.6 & 37.8 & $\mathrm{~N}-\mathrm{C}$ & 1.6 \\
\hline $\begin{array}{l}\text { LU } \\
\text { Luxembourg }\end{array}$ & 172.9 & 2.0 & $6 \%$ & 0.0 & 0.0 & $\mathrm{~N}-\mathrm{C}$ & 0.0 \\
\hline LV - Latvia & 161.4 & 21.5 & $65 \%$ & 5.0 & 2.5 & $\mathrm{~N}-\mathrm{C}$ & 0.2 \\
\hline MT - Malta & 21.0 & 0.0 & $0 \%$ & 11.5 & 5.8 & $\mathrm{~S}$ & 0.4 \\
\hline
\end{tabular}




\begin{tabular}{|c|c|c|c|c|c|c|c|}
\hline $\begin{array}{l}\mathrm{NL} \\
\text { Netherlands }\end{array}$ & 2141.8 & 26.1 & $4 \%$ & 323.3 & 161.7 & $\mathrm{~N}-\mathrm{C}$ & 7.2 \\
\hline PL - Poland & 2655.0 & 248.7 & $53 \%$ & 1016.7 & 508.4 & $\mathrm{~N}-\mathrm{C}$ & 22.4 \\
\hline PT - Portugal & 663.5 & 9.0 & $2 \%$ & 245.9 & 123.0 & $S$ & 7.4 \\
\hline RO - Romania & 911.0 & 54.0 & $23 \%$ & 308.9 & 155.0 & $\mathrm{~N}-\mathrm{C}$ & 6.8 \\
\hline SE - Sweden & 1322.8 & 176.0 & $52 \%$ & 115.2 & 57.6 & $\mathrm{~N}-\mathrm{C}$ & 2.6 \\
\hline SI - Slovenia & 200.9 & 7.7 & $15 \%$ & 42.5 & 21.3 & $\mathrm{~N}-\mathrm{C}$ & 1.0 \\
\hline SK - Slovakia & 454.9 & 82.7 & $35 \%$ & 0.0 & 0.0 & $\mathrm{~N}-\mathrm{C}$ & 0.0 \\
\hline $\begin{array}{l}\text { UK - United } \\
\text { Kingdom }\end{array}$ & 5712.2 & 41.5 & $2 \%$ & 1998.0 & 999.0 & $\mathrm{~N}-\mathrm{C}$ & 44.0 \\
\hline EU-28 & 46214.5 & 1573.9 & $11.8 \%$ & 12827.9 & 6414.9 & & 315.0 \\
\hline
\end{tabular}

Finally, the costs related to the conversion of conventional thermal power plants into cogeneration plants and the investment required for the expansion of the district heating networks are estimated in column $\mathrm{G}$ (Table 5). Expansion costs include costs relating to both heat transport as those incurred in the district heating network itself. It should be noted that the cost of network expansion will vary depending on the region under analysis. Locations where AHDD is high incur smaller expenses (for district heating) than those for regions with a low heat demand, where a lower number of buildings will need to be connected to the district heating network. For those projects located in northern and central Europe, denoted respectively under the "N-C" acronym (see column F of Table 5), it has been assumed that they incur an annual heat demand cost of $45 € / G J$ [8]. The costs of providing heat and cold jointly to those projects located in southern European countries, denoted by the acronym " $\mathrm{S}$ " (column F of Table 5), were assumed to be $60 € / \mathrm{GJ}$ [8]. Note, however, that carrying out an appropriate assessment of the factual potentiality of associating current thermal generating plants to DHNs (district heating networks) requires a detailed analysis of each particular case, in which various techno-economic parameters are taken into account -see [11]. That is an extra feature to this paper, as this analysis is beyond the scope of this paper.

As can be seen in column C (Table 5), about $12 \%$ of the citizens of the EU-28 have access to district heating networks, with significant differences between countries. It is possible to find cases where the contribution of district heating networks to heat demand is virtually zero, as in the case of Spain, and others where the weight of district heating networks is high (nearly 2 out of 3 Danish have access to this technology). A historical of the heat price provided by the district heating networks, the contribution of cogeneration to produce 
electricity, and the percentage of citizens who have access to district heating networks is presented in (Fig. 6), (Fig. 7), and (Fig. 8); Theoretical Background section.

It is possible to see that the length of the pipes for transporting heat from the thermal power station located at Wilhelmshaven $(757 \mathrm{MW})$ to the city of Oldenburg is of more than 60 $\mathrm{km}$ and that this conversion would be feasible from an economic point of view. So it can be assumed conservatively that about $50 \%$ of all the electric power allocable to conventional thermal power plants is located within a reasonable distance to convert these plants in cogeneration plants [11]. This percentage has been obtained - from the database (E-PTR) [104] - after imposing as constraints that only will be valid for conversion to cogeneration plants those conventional thermal power plants with a rated output of over $300 \mathrm{MW}$ placed at a distance of less than $75 \mathrm{~km}$ from towns of more than 100000 inhabitants, which results in about $23 \%$ (this represents a $56 \%$ of the installed capacity of this technology) of all conventional thermal power plants not yet converted to cogeneration plants placed in the EU-28 (in 2013) to comply with these restrictions (see Table 6). This is the reason why in this paper it has been set as a goal that $50 \%$ of the thermal load (domestic and commercial) of the EU-28 is satisfied through the joint use of cogeneration plants and district heating networks.

Table 6. Conventional thermal power plants (not converted to cogeneration power plants) with a rated output of over $300 \mathrm{MW}$ placed at a distance of less than $75 \mathrm{~km}$ from towns of more than 100000 inhabitants. Source: Database of E-PTR [104]

\begin{tabular}{ccc}
\hline $\begin{array}{c}\text { Number of conventional thermal } \\
\text { plants (unconverted) near urban } \\
\text { centers. }\end{array}$ & $\begin{array}{c}\text { Total conventional thermal power } \\
\text { plants (unconverted) near urban } \\
\text { centers. } \\
\text { (GWe) }\end{array}$ & $\begin{array}{c}\text { Total number of } \\
\text { conventional } \\
\text { thermal power } \\
\text { plants }\end{array}$ \\
\hline 393 & 246.5 & 1690 \\
\hline
\end{tabular}

According to (Table 5), if all potentially convertible thermal power plants, those with a rated power of over $300 \mathrm{MW}$ located within $75 \mathrm{~km}$ of urban centers of more than 100000 inhabitants, were converted into cogeneration plants and they would have access to district heating networks, about 6400 PJ of heat could be used, with a low carbon footprint, if an investment of some 315 billion euros will be made. After having consulted the database [104], it was found that in most countries, the limiting factor is, rather than lack of heat loads, the availability of thermal plants. However, in some locations, it was possible to observe the opposite, as groups of thermal power plants located relatively remote or at uneconomical distances to transport heat happened. 
To get a clearer idea of the economic benefits of investing in district heating networks, let us assume that fuel consumption per unit of heat supplied is 1.1 in the case of boilers [105], being meanwhile 0.125 in the case of cogeneration plants [105]. Assuming that the cost of natural gas for domestic consumers was about $15 € / G J$ for the second half of 2014 [106], yearly savings of 93.6 billion euros would be achieved only in fuel for an annual investment 315 billion euros.

This estimate is only intended to give context about the treated magnitudes; in any case, it needs further evaluation case by case to debug this rough approximation; see [11]. It should be noted that, obviously, this amount is in itself an upper limit, which is subject to considerable uncertainty and that some of the conventional thermal plants that here have been supposed to be convertible eventually will not. However, if a greater commitment at the European level in promoting the joint use of district heating networks and cogeneration would be obtained, in the long term, it would be possible to approach the upper limit as new cogeneration power plants were built close to the thermal loads. Certainly, the barriers that the joint use of cogeneration and district heating faces are not technological but institutional and financial; see [107] to know these barriers in detail.

\section{Discussion}

As in most of the district heating networks of the member countries of the European Union that belonged to the former USSR and in the early stages as compared to the rest of the EU, it was common practice to use auxiliary boilers that only generated heat without there being at first a willingness to convert them into cogeneration plants [108-111]. Commonly, they used cheap or subsidised hydrocarbons [112] that had difficulties in burning [113]. With the passage of time, a number of auxiliary boilers from some cities were connected to other thermal generating plants that could use their reject heat. In Prague, what really triggered the connection of the Poříćí II power plant with the associated desulfurised emissions to the existing district heating network, even taking into account that the pipes carrying steam and hot water should have a length of about $40 \mathrm{~km}$ each one, was the realisation of the fact that there was a need to desulfurise emissions from plants that burned dirty fuels [114].

It might be thought that the joint use of cogeneration and district heating networks would only be profitable in the Northern European states due to their cooler climate and greater thermal requirements, rather than be consequently applicable to the rest of the EU-28.

However, the fact that homes in these countries have better insulation has as a consequence that the specific thermal demands are lower (Fig. 20). Moreover, it is unlikely that the thermal loads in buildings will decrease so that the joint use of cogeneration and district heating networks becomes non-viable [115]. On the other hand, usual reductions of heat losses in buildings are not as high as expected in the first instance (the users to see an 
improvement in the efficiency of an energy service that leads to a reduction of the actual cost of the service tend to consume more, causing the known rebound effect) [116]. This effect, although difficult to quantify (but real), might result in a decrease in thermal load reductions of between $10 \%$ and $30 \%$ [116]. The vision of the not or, at least, modest changes in heat demand is based on forecasts conducted by each of the member states. As an example, it is presented the case of Ireland (Table 7), where it is possible to see that for the period 2008-2020, it is expected to increase the thermal energy consumption by only a $0.3 \%$ [117], very much in line with other countries EU-28.

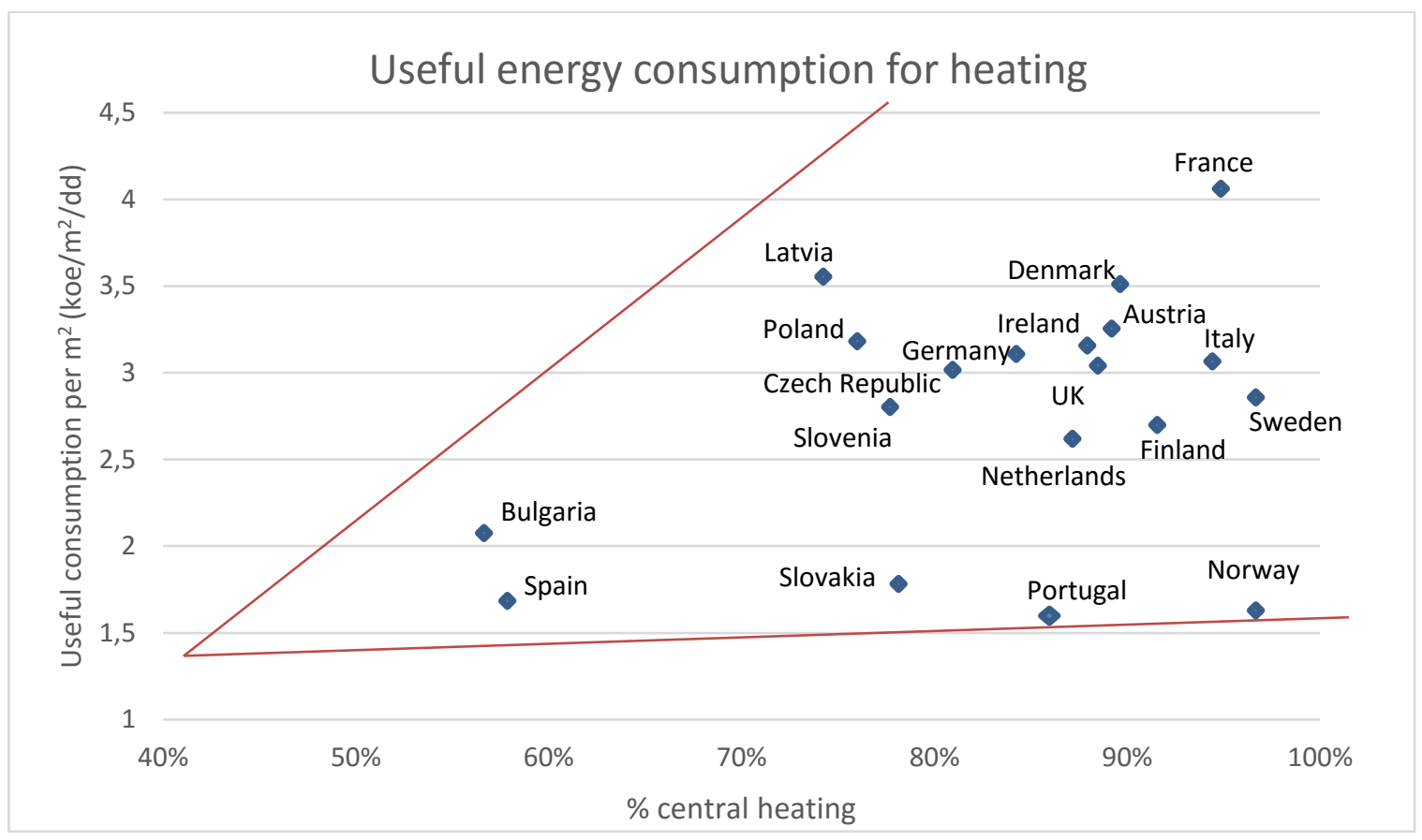

Figure 20. Useful energy consumption for heating in equivalent kilograms of oil per $\mathrm{m}^{2}$ and heating days with respect to the percentage of centralised heating for some EU member states [118] 
Table 7. Thermal energy consumption by sector for Ireland (2008-2020) [117]

\begin{tabular}{|c|c|c|c|c|c|c|c|c|c|c|c|}
\hline & & \multicolumn{3}{|c|}{$\begin{array}{l}\text { Total final demand } \\
\text { (ktoe) }\end{array}$} & \multirow{2}{*}{$\begin{array}{c}\text { Growth (\%) } \\
08-20\end{array}$} & \multicolumn{3}{|c|}{$\begin{array}{l}\text { Average annual } \\
\text { growth (\%) }\end{array}$} & \multicolumn{3}{|c|}{ Sectoral shares (\%) } \\
\hline \multirow{4}{*}{ 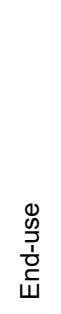 } & & 2008 & 2012 & 2020 & & $\begin{array}{l}08- \\
20\end{array}$ & $\begin{array}{l}08- \\
12\end{array}$ & $12-20$ & 2008 & 2010 & 2020 \\
\hline & Industrial & 139 & 148 & 150 & & 0.6 & 1.5 & 0.2 & 2.5 & 2.8 & 2.6 \\
\hline & Residential & 44 & 43 & 41 & & -0.5 & -0.5 & -0.5 & 0.8 & 0.8 & 0.7 \\
\hline & Services & 15 & 14 & 14 & & -0.5 & -1.0 & -.02 & 0.3 & 0.3 & 0.2 \\
\hline \multicolumn{2}{|c|}{$\begin{array}{l}\text { Total renewable } \\
\text { energies }\end{array}$} & 198 & 205 & 205 & 3.7 & 0.3 & 0.9 & 0.0 & & & \\
\hline \multicolumn{2}{|c|}{ Total consumption } & 5502 & 5209 & 5718 & 4.0 & 0.3 & -1.3 & 1.2 & & & \\
\hline \multicolumn{2}{|c|}{$\begin{array}{l}\text { Heating from } \\
\text { renewable energies }\end{array}$} & & & & & & & & 3.6 & 3.9 & 3.6 \\
\hline
\end{tabular}

Furthermore, there are several reasons why it is easier to increase generation from renewable sources (particularly wind) than from cogeneration. In the EU-28, wind energy (along with hydroelectric power) is the dominant energy source from renewable origins $[119,120]$, being necessary in this case only that the promoter locates a location and would obtain the various needed permits. Because there are usually many locations where to deploy a project, there are high chances that the same is carried out. By contrast, cogeneration is undoubtedly much more restricted because it inevitably has to be used in cities and industries - obviously, the difficulties associated with implementing a district heating network to an entire city are of a different order than those found in obtaining permission for implementing a wind farm.

The cogeneration plants are also subject to more restrictions than those plants that produce heat and electricity separately. This is because although the electricity is cheap and easy to transport over long distances (in Theoretical Background section it is possible to find additional information concerning large-scale heat transportation), heat needs to be generated locally and can only be transported to much shorter distances. Consequently, a heat-generating unit will always be connected to the end user; meanwhile, electricity will feed to the electric grid in general. In other words, the cogeneration plant will have to compete in the heat market with, for example, heat boilers or heat pumps, and in the electricity market with more flexible power plants [121].

Despite these restrictions, it is to be emphasised that a higher CHP and DHNs generalisation (and their associated thermal storage; see Theorecital Background sectio) is of vital importance in reducing overall energy consumption in the EU-28, which obviously 
will impact $\mathrm{CO}_{2}$ emissions. This view has been the one that has enabled Denmark, along with increased energy requirements of buildings, to prevent an increase in its energy consumption over the last 30 years despite having experienced an increase of $70 \%$ of GDP during this period [122].

Literature findings are certainly inconclusive in what district heating networks and cogeneration potential are respected at a pan-European level. In fact, even though some studies have been undertaken for specific countries or regions, such as Sweden [123], Latvia [124], the Baltic States [125], or USA [126], scientific literature has not given the same attention to the potential and the economic and environmental benefits resulting from the implementation of an energy strategy based on a massive increase of the joint use of district heating networks and cogeneration in the EU-28. As a result, and due to the aforementioned lack of attention, a comparison between this paper and other scientific publications is, at least, problematic (in particular, and for Southern Europe countries, attention given has been virtually zero). However, it is possible to indicate that one of the main strengths of this paper is that, by using a simple methodology, its approach and perspective provide both novel results for the scientific literature and new insights to the European Union as a whole about the true potential of this underexploited technology. Paradoxically, this strength of the simple methodology is at the same time a shortcoming due to inaccuracies in the district heating and cogeneration potential assessment, and further research on this issue would be interesting for refinement purposes. Finally, and as another research extension, it would be interesting to evaluate the applicability of other reject heat from other types of thermal power plants such as biomass and nuclear ones for district heating purposes.

\section{Conclusions}

About half of the installed electric capacity in the EU-28, from conventional thermal power plants, is located at an appropriate distance to be able to convert these plants into cogeneration plants and to use their wasted heat in district heating networks. Taking into account the maximum penetration that is economically feasible, from an annualised investment in infrastructures of 315 billion euros, the costs, assignable to fuel, would be reduced by 95 billion euros per year and would save about $6400 \mathrm{PJ}$ of primary energy. This represents about $15 \%$ of the total final energy consumption in the EU-28 in 2013 (46 214.5 PJ). All these savings are achieved from a by-product, such as the waste heat from conventional power plants, currently not utilised in order to meet any thermal load due to their low temperature (about $30{ }^{\circ} \mathrm{C}$ ). If the energy vision, proposed in this paper, were implemented, it would quadruple (from $12 \%$ to $50 \%$ ) the access of the citizens of the EU28 to the technology of district heating networks. This estimate has important political implications as a generalisation of the joint use of cogeneration plants to raise the 
aforementioned temperature, and district heating networks would entail some economic, environmental, and energy security benefits that are necessary for the fulfillment of the legal basis of the H2020 Societal Challenges "Secure, Clean, and Efficient Energy" in a sustainable way. It has been consequently justified that, definitely, the barriers that the proposed new vision face are not of a technological nor of an economic nature but are institutional and financial. It is worth to remark the forecast that, if a policy, committed to the development of district heating networks and cogeneration, is obtained, it would imply that over the next decades more and more power plants will be built in proximity to thermal loads and decommission those located remotely. Finally, and as a possible research extension, it would be interesting to consider reject heat from other thermal power plants, such as biomass and nuclear ones. Even though the latter ones should be considered cautiously due to their typical locations (normally far from heat loads), rejected heat from nuclear power plants might represent a significant increase in the joint use of CHP and DHNs, as currently they represent about $30 \%$ of the electricity provided in the EU-28.

\section{Acknowledgements}

We are grateful to the experts contacted who gave us their support, in particular and especially to Poul Alberg Østergaard (Aalborg Universitet), Capezzali Massimiliano (École Polytechnique Fédérale de Lausanne), Kevin Sartor (Université de Liège), Erwin Cornelis (VITO NV), Chiara Wolter (Ambiente Italia), Alexandra Tudoroiu (COGEN Europe), Olu Ogunbadejo (Department for Environment, Food \& Rural Affairs), Aleksandrs Zajacs (Riga Technical University), and Carsten Magass (Forschungszentrum Jülich $\mathrm{GmbH}$ ). Without their participation, this article would not have been possible.

\section{References}

[1] Ecoheatcool and Euroheat \& Power. The European heat market: Final report. Brussels: Euroheat \& Power; 2006.

[2] Eurostat. Simplified energy balances - annual data. Luxembourg: Eurostat. Accessed at $<$ http://ec. europa.eu/eurostat/en/web/products-datasets/-/NRG_100A $>$ on October 3, 2015.

[3] The Connecticut Academy of Science and Engineering. A study of the feasibility of utilizing waste heat from central electric power generating stations and potential applications. Hartford: The Connecticut Academy of Science and Engineering; 2009. 
[4] IEA. World balance. Paris: IEA. Accessed at $<$ http://www.iea.org/sankey/ $>$ on September 29, 2015.

[5] European Environment Agency. Progress on energy efficiency in Europe; 2015. Accessed at $<\mathrm{http}$ //www.eea.europa.eu/data-and-maps/indicators/progress-on-energyefficiency-in-europe-2/assessment $>$ on October 7, 2015.

[6] Bordin C, Gordini A, Vigo D. An optimization approach for district heating strategic network design. European Journal of Operational Research 2016 (In Press). http://dx.doi.org/10.1016/j.ejor.2015.12.049

[7] Cooper SJG, Hammond GP, Norman JB. Potential for use of heat rejected from industry in district heating networks, GB perspective. Journal of the Energy Institute 2016;89(1):5769. http://dx.doi.org/10.1016/j.joei.2015.01.010

[8] Köfinger M, Basciotti D, Schmidt RR, Meissner E, Doczekal C, Giovannin A. Low temperature district heating in Austria: Energetic, ecologic and economic comparison of four case studies. Energy 2016 (In Press).

[9] International Energy Agency. Energy technology perspectives 2015: Mobilising innovation to accelerate climate action. Paris: Organisation for Economic and Co-operation and Development; 2015.

[10] Euroheat \& Power. District heating and cooling-statistics. Brussels: Euroheat \& Power; 2015.

[11] Colmenar-Santos A, Rosales-Asensio E, Borge-Diez D, Collado-Fernández E. Evaluation of the cost of using power plant reject heat in low-temperature district heating and cooling networks. Applied Energy 2016; 15:8. http://dx.doi.org/10.1016/j.apenergy.2015.10.161

[12] Boysen H. Hydraulic balance in a district cooling system. Nordborg: Danfoss district energy; 2003.

[13] Combined Heat and Power Group. Combined heat and electrical power generation in the United Kingdom: Report to the Secretary of State for Energy. London: H.M. Stationery Off.; 1979.

[14] Euroheat \& Power. District heating in buildings. Brussels: Euroheat \& Power; 2011.

[15] International Energy Agency. Cogeneration and district energy. Paris: International Energy Agency; 2009.

[16] Department for Environment Food and Rural Affairs. Analysis of the UK potential for combined heat and power. London: Queen's Printer and Controller of HMSO; 2007. 
[17] Osborne M. Making electricity transmission smarter. Cambridge: Cambridge University Energy Network; 2013.

[18] Kelly SJ, Pollit MG. An assessment of the present and future opportunities for combined heat and power with district heating (CHP-DH) in the United Kingdom. Energy Policy 2012;38(11):6936-6945. http://dx.doi.org/10.1016/j.enpol.2010.07.010

[19] Woods P, Turton A. Smart heat grids - the potential for district heating to contribute to electricity demand management to facilitate renewable and nuclear electricity generation. Abingdon: The Solar Energy Society Conference C92; 2010.

[20] Werner S. Benefits with more district heating and cooling in Europe. Rome: 20th World Energy Conference; 2007.

[21] Euroheat \& Power. District heating and cooling country by country survey 2015. Brussels: Euroheat \& Power; 2015.

[22] Orchard W. Cost of transmitting $2 \mathrm{GW}$ of heat $140 \mathrm{~km}$ : Also longest heat main in Europe $60 \mathrm{~km}$. London: Orchard Partners London Ltd.; 2011. Accessed at $<$ https://groups.google.com/forum/\#!msg/energy-discussion-group/hOqhtmoHic8/0BrO uaIJ3V8J> on March 11, 2014.

[23] Riddle A. District heating \& the future smart cities approach. Copenhagen: Ramboll Group A/S; 2013.

[24] Pirouti M. Modelling and analysis of a district heating network. Cardiff: University of Cardiff; 2013. 137 p.

[25] Kitsios K, Chrysis I. Assessment of national potential for cogeneration in Cyprus. Nicosia: Republic of Cyprus Ministry of Commerce, Industry and Tourism Energy Service; 2009.

[26] Dyrelund A. The Future of the energy supply: Smart energy cities. Euroheat \& Power 2012 (English Edition);9(1):12-15. Accessed at <https://www.stateofgreen.com/ CMSPages/GetAzureFile.aspx?path $=\sim \% 5$ Ccache $\% 5$ Cstateofgreen $\% 5 C 33 \% 5 C 3305$ a15939c0-4c5f-ae58-70883774a7d4.pdf\&hash=3e2d92789d181deb3076da90e24ce0ab e6548c7 3131c70d1d8e172d7661ebec9> on March 11, 2014.

[27] Worm J. Delrapport 3 miscellaneous investigations: $\mathrm{CO}_{2}$ reductions in low-energy buildings and communities by implementation of low-temperature district systems demonstration cases in Energyflexhouse and Boligforeningen Ringgården, Journalnr. 63011-0152. Copenhagen: Danish Energy Agency; 2011. Accessed at $<$ http://fjvu.dk/si tes/default/files/delra pport_3_miscellaneous_investigations.pdf $>$ on March 11, 2014.

[28] Dong Energy. The Studstrupværket CHP plant. Skødstrup: Dong Energy A/S; 2007. 
[29] Wagner I. Local success stories: Prague district heating system. Brussels: Ecoheat4.eu; 2011. Accessed at <http://ecoheat4.eu/en/Country-by-country-db/Czech-Republic/LocalSuccess-Stories/> on March 11, 2014.

[30] Piskac M. Prague district heating system: Application for 1st Global District Energy Climate Awards. Prague: Pražská Teplárenská A.S; 2009. Accessed at <http://www.co penhagenenergysummit.org/applications/Prague\%20Czech\%20Rep-Dis trict\%20Energ y\%20Climate\%20Award.pd f> on March 11, 2014.

[31] Harvey LDD. Energy and the new reality 1: Energy efficiency and the demand for energy services. 1st ed. Oxon: Routledge; 2010.

[32] Wade DW. District heating conversion from steam to hot water at the Savannah Regional Hospital. Marietta: RDA Engineering; 1995.

[33] De Souza GFM. Thermal power plant performance analysis. 1st ed. London: SpringerVerlag London Limited; 2012. http://dx.doi.org/10.1007/978-1-4471-2309-5

[34] Burzynski R, Crane M, Yao R, Becerra VM. Low temperature district heating network serving experimental zero carbon homes in Slough, UK. Copenhagen: DHC13, the 13th International Symposium on District Heating and Cooling; 2012.

[35] Ramboll Energy. Lavenergi Fjernvarmekoncepter. Copenhagen: Ramboll; 2010.

[36] Urecon. Pre-insulated municipal service pipe system. Quebec: Urecon Ltd.; 2009. Accessed at <http://www.urecon.com/applications/municipal_pipe.html > on March 17, 2014.

[37] Eliseev K. District heating systems in Finland and Russia. Mikkeli: Mikkeli University of Applied Sciences; 2011.

[38] Hepbasli A. Low exergy (LowEx) heating and cooling systems for sustainable buildings and societies. Renewable and Sustainable Energy Reviews 2012;16:74-104. http://dx.doi.org/10.1016/j.rser.2011.07.138

[39] Allegrini J, Orehounig K, Mavromatidis G, Ruesch F. A review of modelling approaches and tools for the simulation of district-scale energy systems. Renewable and Sustainable Energy Reviews 2015;52:1391-1404. http://dx.doi.org/10.1016/j.rser.2015.07.123

[40] Pomper DE. Electric storage: Technologies and regulation. Silver Spring: National Regulatory Research Institute; 2011.

[41] Pauli GA. The blue economy: 10 Years, 100 innovations, 100 million jobs. 1st ed. Taos: Paradigm Publications; 2010. 
[42] Danish Energy Agency. Technology data for energy plants: Generation of electricity and district heating, energy storage and energy carrier generation and conversion. Fredericia: Energinet; 2012.

[43] Taylor P, Bolton R, Stone D, Zhang XP, Martin C, Upham P. Pathways for energy storage in the UK. York: The Centre for Low Carbon Futures; 2012.

[44] Dirección General de Energía. The future role and challenges of energy storage. Brussels: European Commission; 2013.

[45] Macnaghten J. Utility scale pumped heat electricity storage. Fareham: Isentropic Ltd; 2009.

[46] IEA-ETSAP. Thermal energy storage: Technology brief. Bonn: International Renewable Energy Agency; 2013.

[47] Schröder D. Introducing additional heat storage to the hässelby chp plant: A case study on economic and ecological benefits achievable with heat storage in a deregulated electricity market. Stockholm: KTH School of Industrial Engineering and Management; 2011.

[48] International Energy Agency. Combined heat and power: Evaluating the benefits of greater global investment. Paris: International Energy Agency; 2008.

[49] Overbye P. Thermal storage in district heating systems. Copenhagen: Ramboll; 2012. Accessed at <http://www.districtenergy.org/assets/pdfs/03AnnualConference/Mo ndayA/A4.1OVERBYERamboll-A4ThermalStoresinDH-slidesonly.pdf $>$ on February 27, 2014.

[50] Poeuf P, Senejean B, Ladaurade C. District cooling system: The most efficient system for urban applications. Paris: Climespace - GDF Suez; 2010.

[51] Thornton R. IDEA report: The district energy industry. Westborough: International District Energy Association; 2005.

[52] Capital Cooling. EU district cooling market and trends. Stockholm: Capital Cooling; 2013.

[53] Skagestad B, Mildenstein P. District heating and cooling connection handbook. Paris: Interntational Energy Agency. IEA District Heating and Cooling; 2001.

[54] Wulfinghoff DR. Energy efficiency manual. 1st ed. Montgomery County: Energy Institute Press; 1999.

[55] Kavanaugh S. How air-conditioners and heat pumps work. Northport: Energy Information Services; 2011. 
[56] Medved S. Energy production: Generators of cold chillers. Maastrich: CaubergHuygen Consulting Engineers BV; 2013.

[57] Jamadar VM, Patil AM. Investigation of performance analysis of compressor cooling in vapour compression system. International Journal of Advanced Engineering Research and Studies 2012; 2(1):29-31.

[58] Sellars B, Barbour A. Technical report: Geothermal heat pump study. Auckland: Beca Carter Hollings \& Ferner Ltd; 2009.

[59] Tovey K. ENV-2D02 Energy conservation: Section 11. Norwich: University of East Anglia; 2006.

[60] Baechler MC. Energy renovations HVAC: A guide for contractors to share with homeowners. Richland: Pacific Nothwest National Laboratory; 2011.

[61] Zimny J, Michalak P, Szczotka K. Polish heat pump market between 2000 and 2013: European background, current state and development prospects. Renewable and Sustainable Energy Reviews 2015;48:791-812. http://dx.doi.org/10.1016/j.rser.2015.04.005

[62] Jolly A. Energy efficiency of buildings and renewable energy. Hurup: Nordic Folkecenter for Renewable Energy; 2006.

[63] U.S. Department of Energy. Use low-grade waste steam to power absorption chillers. Washington: Industrial Technologies Program Energy Efficiency; 2006.

[64] Srikhirin P, Aphornratana S, Chungpaibulpatana S. A review of absorption refrigeration technologies. Amsterdam: Renewable and Sustainable Energy Reviews 2001;5(4):343-372. http://dx.doi.org/10.1016/s1364-0321(01)00003-x

[65] Energy Management Association of New Zealand. Energy audit standard for process heat systems: A standard for the auditing of the energy efficiency of direct and indirect heating systems. Wellington: Energy Management Association of New Zealand; 2012.

[66] Brown RBY. An experimental study of heat driven absorption cooling systems. Salford: University of Salford; 1990.

[67] Bhatia A. Overview of vapor absorption cooling systems. Stony Point: Continuing Education and Development; 2011.

[68] Labus J. Modelling of small capacity absorption chillers driven by solar thermal energy or waste heat. Tarragona: Universitat Rovira i Virgili; 2011.

[69] ATECYR. Equipos de absorción. Madrid: Asociación Española de Climatización y Refrigeración; 2008. 
[70] Hübner V, Kallmann K, Piller S, Thamling N, Hesse D, Wetzel A. Meeting cooling demands in summer by applying heat from cogeneration. Berlin: Berliner Energieagentur $\mathrm{GmbH}$; 2008. Accessed at <http://www.chaleurfraicheur.org/doc/Publis hable_Report_FINAL.pdf $>$ on March 8, 2014.

[71] Basel II, Ahmed WH. Thermoelectric power generation using waste-heat energy as an alternative green technology. Recent Patents on Electrical Engineering 2009;2:27-39. http://dx.doi.org/10.2174/1874476110902010027

[72] ICF International. Technology characterization: Steam turbines. Washington DC: Environmental Protection Agency; 2008.

[73] Elsaket G. Simulating the integrated solar combined cycle for power plants application in Libya. Cranfield: Cranfield University; 2007.

[74] Lowe R. Combined heat and power considered as a virtual steam cycle heat pump. Energy Policy 2011;39:5528-5534. http://dx.doi.org/10.1016/j.enpol.2011.05.007

[75] Fahlen E, Ahlgren EO. Accounting for external costs in a study of a Swedish districtheating system: An assessment of environmental policies. Energy Policy 2010;28:49094920. http://dx.doi.org/10.1016/j.enpol.2010.03.049

[76] Cortes Generales. Diario de sesiones del Congreso de los Diputados, 8 de marzo de 2006. Núm. 507. Madrid: Congreso de los Diputados; 2006.

[77] UNEP. Thermal energy equipment. Accessed at <www.retscreen.net/fichier.php/ $1000>$ on December 17, 2013.

[78] Uche-Marcuello FJ. Thermoeconomic analysis and simulation of a combined power and desalination plant. Zaragoza: Universidad de Zaragoza; 2000.

[79] Climate and Energy Fund. Smart cities and initiative. Vienna: Climate and Energy Fund; 2013.

[80] European technology platform on renewable heating and cooling. Strategic research and innovation agenda for renewable heating \& cooling. Luxembourg: European Union; 2013.

[81] Gadd H. To measure is to know! Lund: Lund University; 2012.

[82] DHC+. District heating \& cooling: Strategic research agenda. Brussels: Euroheat \& Power; 2012.

[83] Møller-Jørgensen J. R\&D storage activities in Denmark and EU. Fredericia: Energinet; 2013. 
[84] Wu W, Wang B, Shi W, Li X. An overview of ammonia-based absorption chillers and heat pumps. Renewable and Sustainable Energy Reviews 2014;31:681-707.

[85] Kristensen S. The backbone of the modern energy system. Frederiksberg: Danish Board of District Heating; 2010. Accessed at <http://dbdh.dk/the-backbone-of-themodern-energy-system/> on January 17, 2014.

[86] Dyrelund A. Smart energy cities: Seminar in DG17 28.09.2011. Accessed at $<$ https://stateofgreen.com/files/download/325> on December 17, 2013.

[87] DESIRE-project. Guidelines to promote chp concepts with heat accumulators and the perspective of chp plants and other technologies that use thermal energy storage and their implementation in the European Union. Aalborg: Aalborg University; 2007.

[88] Schmidt R, Fevrier N, Dumas P. Key to innovation integrated solution: Smart thermal grids. Brussels: Smart Cities Stakeholder Platform; 2013.

[89] Elsman P. Conpenhagen district heating system. Copenhagen: First Global District Energy Climate Awards; 2009.

[90] Elleriis J. Heat Planning in the Greater Copenhagen Area. Copenhagen: Heat Plan Copenhagen; 2011.

[91] Dyrelund A. European energy efficiency legislation adopts 35 years of Danish experience. Copenhagen: Ramboll; 2011.

[92] Ministry of Environment and Energy. Denmark's second national communication on climate change. Copenhagen: Danish Environmental Protection Agency; 1997.

[93] Dyrelund A, Kozùowski W. DH/CHP in EU smart energy cities. Wrocław: Ramboll; 2012.

[94] Danish Ministry of Energy, Utilities and Climate. Electricity, district heating and natural gas supply. Copenhagen: Danish Ministry of Energy, Utilities and Climate; 2012. Accessed at <http://www.efkm.dk/en/climate-energy-and-building-policy/denmark /energy-supply-and-efficiency/electricity-district-heating> on September 30, 2015.

[95] DBDH. Forsyning Helsingør: Portfolio items. Accessed at $<\mathrm{http}: / / \mathrm{dbdh}$.dk/portfolio items/forsyning-helsingor/> on September 30, 2015.

[96] VEKS. Annual report 2012. Albertslund: VEKS; 2013.

[97] Aalborg Universitet. Heat roadmap Europe 2050. Aalborg: Aalborg Universitet; 2013.

[98] DHC+ Technology Platform. District heating \& cooling: A vision towards 2020 2030-2050. Brussels: DHC+ Technology Platform; 2009. 
[99] Thornton R. Copenhagen's district heating system: Recycling waste heat reduces carbon emissions and delivers energy security. Westborough: International District Energy Association; 2009.

[100] Eurostat. Infrastructure - electricity - annual data. Luxembourg: Eurostat. Accessed at $<$ http://ec.europa.eu/eurostat/en/web/products-datasets/-/NRG_113A $>$ on October 2, 2015 .

[101] Eurostat. Combined heat and power (CHP) data 2005-2013. Luxembourg: Eurostat. Accessed at $<$ http://ec.europa.eu/eurostat/web/energy/data $>$ on October 2, 2015.

[102] Eurostat. Eurostat statistics explained: Consumption of energy. Luxembourg: Eurostat. Accessed at <http://ec.europa.eu/eurostat/statistics-explained/index.php/Con sumption_of_e nergy> on September 29, 2015.

[103] LEKA. New district heating countries. Vilnius: Lithuanian Energy Consultants Association; 2012.

[104] E-PTR. The European Pollutant Release and Transfer Register. Copenhagen: European Environment Agency European Environment Agency. Accessed at $<$ http://prt r.ec.europa.eu/FacilityLevels.aspx $>$ on October 3, 2015.

[105] Riddle A. District energy \& smart energy grids experience from Denmark. London: Rambøll Energy; 2013.

[106] Eurostat. Gas prices for domestic consumers - bi-annual data. Luxembourg: Eurostat. Accessed at <http://ec.europa.eu/eurostat/en/web/products-datasets/-/NRG_PC_202> on October 3, 2015.

[107] Colmenar-Santos A, Rosales-Asensio E, Borge-Diez D, Mur-Pérez F. Cogeneration and district heating networks: Measures to remove institutional and financial barriers that restrict their joint use in the EU-28. Energy 2015;85:403-414.

[108] Martinot E. Investments to improve the energy efficiency of existing residential buildings in countries of the former Soviet Union. Washington: World Bank; 1997.

[109] Danish Board of District Heating. District heating history. Frederiksberg: Danish Board of District Heating. Accessed at $<\mathrm{http}: / / \mathrm{dbdh} . \mathrm{dk} /$ district-heating-history $/>$ on February 19, 2014.

[110] Gaigalis V, Markevicius A, Katinas V, Skema R, Tumosa A. Analysis of energy transition possibilities after the decommission of a nuclear power plant in Ignalina region in Lithuania. Renewable and Sustainable Energy Reviews 2013;24:45-56.

[111] Streimikiene D, Ciegis R, Grundey D. Promotion of energy efficiency in Lithuania. Renewable and Sustainable Energy Reviews 2008;12:772-789. 
[112] Biomass Cogeneration Network. Current situation on CHP and biomass CHP in the national energy sector. Pikermi: Biomass Cogeneration Network; 2001.

[113] Alternative Petroleum Technologies. Fuel oil emulsions. Reno: Alternative Petroleum Technologies; 2013. Accessed at $<$ http://www.altpetrol.com/en/2d-pd-foe.ht ml> on February 19, 2014.

[114] CEZ Group. The Porici power stations. Prague: CEZ Group; 2014. Accessed at $<$ http://www.cez.cz/en/power-plants-and-environment/coal-fired-power plants/cr/porici.html $>$ on February 19, 2014.

[115] Wan KKW, Li DHW, Liu D, Lam JC. Future trends of building heating and cooling loads and energy consumption in different climates. Building and Environment 2011;46(1):223-234.

[116] Sorrell S. The rebound effect: An assessment of the evidence for economy-wide energy savings from improved energy efficiency. London: UK Energy Research Centre; 2007.

[117] Walker N, Scheer J, Clancy M, Ó Gallachoir B. Energy forecasts for Ireland to 2020. Dublin: Sustainable Energy Ireland; 2010.

[118] ENERDATA. Quantitative evaluation of explanatory factors of the lower energy efficiency performance of France for space heating compared to European benchmarks. Angers: Agence de l'Environnement et de la Maîtrise de l'Energie; 2011.

[119] Hinrichs-Rahlwes R. Sustainable energy policies for Europe: Towards 100\% renewable energy. 1st ed. Boca Raton: CRC Press; 2013.

[120] Eurostat. Electricity generated from renewable energy sources, EU-28, 2003-13 YB15. Luxembourg: Eurostat. Accessed at <http://ec.europa.eu/eurostat/statistics-expl ained/index.php?title=File:Electricity_generated_from_renewable_energy_sources,EU28,_2003\%E2\%80\%9 313_YB15.png\&oldid=238269> on October 4, 2015.

[121] Pantaleo A, Candelise C, Bauen A, Shah N. ESCO business models for biomass heating and CHP: Profitability of ESCO operations in Italy and key factors assessment. Renewable and Sustainable Energy Reviews 2014;30:237-253.

[122] Traberg RL. District energy: The Danish experience. London: Royal Danish Embassy; 2008.

[123] Di Lucia L, Ericsson K. Low-carbon district heating in Sweden - Examining a successful energy transition. Energy Research \& Social Science 2014;4:10-20. 
[124] Ziemele J, Gravelsins A, Blumberga A, Vigants G, Blumberga D. System dynamics model analysis of pathway to 4th generation district heating in Latvia. Energy 2015 (In Press).

[125] Ziemele J, Pakere L, Blumberga D. The future competitiveness of the non-Emissions Trading Scheme district heating systems in the Baltic States. Applied Energy 2016;162:1579-1585.

[126] Christian Gils H, Cofala J, Wagner F, Schöpp W. GIS-based assessment of the district heating potential in the USA. Energy 2013;58:318-329. 